\title{
Understanding long-term (1982-2013) multi-decadal change in the equatorial and subtropical South Atlantic climate
}

\author{
Edward K. $\operatorname{Vizy}^{1} \cdot \operatorname{Kerry}$ H. $\operatorname{Cook}^{1}$
}

Received: 11 March 2015 / Accepted: 25 May 2015 / Published online: 6 June 2015

(C) The Author(s) 2015. This article is published with open access at Springerlink.com

\begin{abstract}
High-resolution observations along with atmospheric and oceanic reanalyses are diagnosed to understand how and why southeastern Atlantic SSTs have changed over the 1982-2013 period. Multiple datasets are used to evaluate confidence. Results indicate significant SST warming trends (0.5-1.5 K per 32-years) along the Guinean and Angolan/Namibian Coasts, and a cooling trend $(-0.10$ to $-0.60 \mathrm{~K}$ per 32-years) over the subtropical South Atlantic between $18^{\circ} \mathrm{S}$ and $28^{\circ} \mathrm{S}$. SST trends are shown to vary over the annual cycle with the greatest changes occurring during November-January. Analysis of the ocean surface heat balance reveals that the austral summer SST warming trend along the Angolan/Namibian Coast is associated with an increase in the net downward atmospheric heat flux. In addition, there is a decrease in coastal upwelling due to circulation changes related to a poleward shift of the South Atlantic subtropical anticyclone and an intensification of the southwestern African thermal low. The cooling trend over the subtropical South Atlantic is also associated with the poleward shift of the South Atlantic anticyclone, as stronger surface winds enhance latent heat loss from the ocean over this region. Positive SST trends along the Guinean coast are found to be primarily associated with changes internal to the ocean, specifically, reduced coastal upwelling, diffusion, and enhanced horizontal transport of warmer water. These results highlight the need to better understand South Atlantic subtropical anticyclone and the continental thermal low interactions and their implications for present day climate variability and future climate change.
\end{abstract}

Edward K. Vizy

ned@jsg.utexas.edu

1 Department of Geological Sciences, Jackson School of Geosciences, The University of Texas at Austin, 1 University Station C1100, Austin, TX 78712, USA
Keywords South Atlantic climate variability · Air-sea interactions · South Atlantic SST trends · Angolan thermal low $\cdot$ South Atlantic anticyclone $\cdot$ African climate trends

\section{Introduction}

Climate variations over the South Atlantic and adjacent continents have long been linked to equatorial and South Atlantic SST variations at synoptic to decadal timescales (e.g., Hastenrath and Heller 1977; Shannon et al. 1986; Walker 1990; Zebiak 1993; Jury 1995; Nobre and Shukla 1996; Chang et al. 1997; Ruiz-Barradas et al. 2000; Sutton et al. 2000; Fu et al. 2001; Sterl and Hazeleger 2003; Xie and Carton 2004), yet the relationships between the SSTs and climate variations are not yet fully understood, especially in the context of the ongoing global warming signal. While improvements in high-resolution, satellite-derived observations over the past decade have enhanced our ability to evaluate and understand sub-decadal ocean/atmosphere interactions over remote regions such as the South Atlantic, understanding longer-term variations are generally hampered by the lack of reliable, comprehensive observational gridded datasets. One way to circumvent this lack of information is to use other resources such as atmospheric models and blended observational/model reanalysis datasets to better understand decadal climate variations and their association with South Atlantic SSTs.

The purpose of this study is to understand how and why southeastern Atlantic SSTs change over the multidecadal timescale of the satellite era (i.e., 1982-2013), and how these changes are connected to the regional climate. Observations and various atmospheric and oceanic reanalysis datasets are examined to analyze changes over the 32-year period. The goal is an improved understanding of 
the long-term changes over the South Atlantic as this investigation is intended as a first step towards improving our understanding and ability to predict South Atlantic climate variability.

Section 2 provides background on the South Atlantic and it's regional climate. The datasets analyzed are described in Sect. 3, while the results are presented in Sect. 4. Conclusions are drawn in Sect. 5.

\section{Background}

It has long been thought that atmosphere/ocean interactions play an integral role in determining the climate and its variability over the South Atlantic. The large-scale atmospheric circulation is dominated by the semi-permanent South Atlantic subtropical anticyclone which is usually located between $20^{\circ} \mathrm{S}$ and $30^{\circ} \mathrm{S}$ (Höflich 1984; Peterson and Stramma 1991; Rodwell and Hoskins 2001). Another semi-permanent feature is the inter-tropical convergence zone (ITCZ) which ranges in position over the Atlantic near $2^{\circ} \mathrm{N}$ during the boreal winter and $10^{\circ} \mathrm{N}$ during the boreal summer.

Land-based atmospheric circulation features are also relevant to the South Atlantic climate. Such features include the South Atlantic convergence zone (SACZ), which extends southeastward from the Amazon Basin over the western South Atlantic basin (Kodama 1992; Lenters and Cook 1995, 1999), and the continental thermal low, or Angolan low, over southwestern Africa (Peterson and Stramma 1991; Mason 1995; Hardman-Mountford et al. 2003; Cook et al. 2004; Reason and Jagadheesha 2005; Vigaud et al. 2009). At mid-levels the Angolan low is capped by the Kalahari anticyclone, or Botswana High, which is typical of shallow continental thermal low systems (e.g., Rácz and Smith 1999). Both the SACZ and the Angolan low exhibit distinct seasonal cycles, with strongest intensities during the austral summer.

The near-surface ocean circulation in the South Atlantic is primarily wind driven (Anderson and Gill 1975). Numerous studies (e.g., Peterson and Stramma 1991; Stramma and England 1999; Hardman-Mountford et al. 2003) detail the major near-surface oceanic circulation features including the South Atlantic subtropical gyre which is bounded by the Benguela Current to the east, the southern branch of the Southern Equatorial Current to the north, the Brazil Current to the west, and the South Atlantic Current to the south. Off the Angolan coast a smaller, wind-driven cyclonic gyre is also observed centered at about $10^{\circ} \mathrm{S}$ and $9^{\circ} \mathrm{E}$. This gyre is bounded by the Southern Equatorial Countercurrent to the north, the Angola Current to the east, and the southern branch of the Southern Equatorial
Current to the west, and the Angola/Benguela front to the south (Colberg and Reason 2006). Along the equator is the westward-flowing Equatorial Current, flanked to the north by the eastward flowing North Equatorial Counter Current around $3^{\circ} \mathrm{N}-10^{\circ} \mathrm{N}$, and to the south by the South Equatorial Counter Current around $6^{\circ} \mathrm{S}-9^{\circ} \mathrm{S}$.

Studies examining the influence of air-sea interactions on various aspects of climate variability over the South Atlantic basin have identified several modes of variability. One such mode of tropical Atlantic variability is the SST gradient mode (Hastenrath and Greischar 1993; Chiang et al. 2002; Barreiro et al. 2004) in which it is thought that an anomalous cross-equatorial SST gradient generates lowlevel flow from the cooler to warmer hemisphere, affecting low-level moisture convergence and regional rainfall.

Two El Niño-like phenomena in the South Atlantic, namely Atlantic Niños and Benguela Niños, have also been identified (Servain 1991; Ruiz-Barradas et al. 2000). Both Atlantic and Benguela Niños are analogous to Pacific El Niño events, and are characterized by a warming of tropical and subtropical eastern South Atlantic SSTs in association with a relaxation of the wind stress over the equatorial Atlantic (Florenchie et al. 2003; Grodsky et al. 2006; Rouault et al. 2007). Atlantic Niños occur in the equatorial cold tongue region and are phase locked to austral winter (Keenlyside and Latif 2007), while Benguela Niños occur further south off the coast of Angola near $15^{\circ} \mathrm{S}$ during the austral fall (Florenchie et al. 2003; Rouault et al. 2007; Richter et al. 2010). Studies (e.g., Reason et al. 2006; Polo et al. 2008; Rouault et al. 2009) have indicated that these two phenomena may be physically connected in some instances and could be part of the same mode of variability.

Still another mode of interannual variability is the South Atlantic subtropical dipole mode (Venegas et al. 1997; Morioka et al. 2011, 2012; Nnamchi et al. 2011; Yuan et al. 2014). This mode is characterized by a northeast/southwest SST dipole pattern over the subtropical South Atlantic, and is linked to changes in wind and sea level pressure associated with changes in the South Atlantic subtropical anticyclone (Venegas et al. 1997; Fauchereau et al. 2003). SST variations associated with this mode have been linked to latent heat flux anomalies resulting from the circulation changes (Fauchereau et al. 2003; Sterl and Hazeleger 2003). These atmospheric and oceanic anomalies are found to influence southern African climate variability (Vigaud et al. 2009).

While most of the modes of South Atlantic variability discussed above are found to operate on inter-annual to intra-seasonal timescales, there is evidence that decadal timescale variability may also be associated with similar mechanisms (e.g., Chang et al. 1997; Servain et al. 2014). An improved understanding of the long-term trends of climate variability over the South Atlantic, including the 
atmospheric and/or oceanic mechanisms responsible for these changes, is needed and that is the purpose of this paper.

\section{Datasets}

Atmospheric and oceanic reanalysis products are utilized to identify and investigate long-term trends over the South Atlantic. Reanalyses incorporate available instrumentbased and satellite-derived measurements into a data assimilation system to provide estimates of atmospheric and oceanic variables at regular temporal intervals on global grids over an extended period. Over data sparse regions, values are estimated based on the governing equations in the assimilation system's model which are constrained by nearby observations. Thus, an advantage of reanalyses is that they provide more information than is directly observed, allowing for a more complete evaluation of the climate system.

While the benefits of the reanalysis products are significant, it is also important to understand their limitations. One such limitation is that the observational constraints can factor into the accuracy of the data products. For example, observations are not uniformly distributed, so highly populated regions are heavily constrained by observations, while remote areas are more loosely constrained so data over remote regions, such as the open oceans, is more dependent on the assimilation system's model. Other fields that are generally not observed (e.g., surface and atmospheric heating rates) are almost completely model-dependent. Other fields are observed, but not accounted for in the assimilation (e.g., precipitation and cloud over, depending on the reanalysis product). Observations incorporated into the assimilation system and the assimilation calculation itself can change over time (Dee et al. 2014), resulting in artificial shifts in the reanalysis output time series.

Because of these limitations, appropriate care must be taken when evaluating reanalysis products. Here, this risk is minimized by utilizing multiple reanalyses, evaluating physical processes for their plausibility, and comparing with more direct observations whenever possible.

Four global atmospheric reanalyses are selected for analysis. They include the $1.5^{\circ}$ horizontal resolution European Centre for Medium-Range Weather Forecasts ERA-Interim reanalysis (ERAI; Dee et al. 2011), the $0.5^{\circ}$ latitude $\times 2 / 3^{\circ}$ longitude horizontal resolution National Aeronautics and Space Administration (NASA) ModernEra Retrospective Analysis for Research and Applications (MERRA; Rienecker et al. 2011), the $2.5^{\circ}$ resolution upper-air/ $\sim 1.8^{\circ}$ resolution surface National Center for Environmental Prediction (NCEP)/Department of Energy (DOE) Reanalysis 2 (NCEP2; Kanamitsu et al. 2002), and the $1.25^{\circ}$ resolution Japan Meteorological Agency's 55-year Reanalysis (JRA-55; Kobayashi et al. 2015). Each of these reanalyses provide output from 1979 until present.

Three oceanic reanalyses are also analyzed. One is the NCEP Global Ocean Data Assimilation System (GODAS; Behringer and Xue 2004). GODAS is based on a quasiglobal configuration of the GFDL MOM.v3 model. The domain extends from $75^{\circ} \mathrm{S}$ to $65^{\circ} \mathrm{N}$, and has a spatial resolution of $1^{\circ}$ enhanced to $1 / 3^{\circ}$ in the meridional direction within $10^{\circ}$ if the equator. GODAS has 40 vertical levels with $10 \mathrm{~m}$ resolution in the upper $200 \mathrm{~m}$ of the ocean. Data is available from 1980 to present.

Also analyzed is the ECMWF Ocean Reanalysis S3 (ORA-S3; Balmaseda et al. 2008). ORA-S3 ocean data assimilation system is based upon the HOPE ocean model. The horizontal resolution is $1^{\circ}$ resolution with the meridional resolution gradually increasing toward the equator to $0.3^{\circ}$ resolution. There are 29 vertical levels with $10 \mathrm{~m}$ resolution in the upper ocean. Data is available from 1959 to 2011.

The third ocean reanalysis used here is the ECMWF Ocean Reanalysis S4 (ORA-S4; Balmaseda et al. 2013). ORA-S4 uses the NEMOVAR data assimilation system based on the NEMO ocean model. The horizontal resolution is the same as ORA-S3, however ORA-S4 has 42 vertical levels with about $10-15 \mathrm{~m}$ resolution in the upper $200 \mathrm{~m}$ of the ocean. While the ORA-S4 record extends from 1958 to present, data is produced in real time from January 2010 onwards and is not recommended for climate trend examination after 2009. Thus, our examination of this dataset extends through 2009.

Various observational and satellite-derived datasets are also used. These include the 1981-2014 daily $0.25^{\circ}$ resolution blended analysis for SSTs (NOAA-OI; Reynolds et al. 2007), the $2.5^{\circ}$ resolution 1983-2009 International Satellite Cloud Climatology Project cloud dataset (ISCCP; Rossow and Schiffer 1999), the $1^{\circ}$ resolution 1982-2009 NASA AVHRR PATMOS-x cloud dataset (PATMOSX; Heidinger et al. 2012, Foster and Heidinger 2013), and the $5^{\circ}$ resolution 1860-2013 UK. Met Office Hadley Centre's monthly historical gridded mean sea-level pressure dataset (HadSLP2; Allan and Ansell 2006). For rainfall the $2.5^{\circ}$ resolution 1979-2014 GPCP version 2.2 combined precipitation dataset (GPCP; Adler et al. 2003), the $0.5^{\circ}$ resolution 1901-2013 University of East Anglia Climate Research Unit monthly rainfall dataset version 3.22 (CRUTS; Harris et al. 2014), and the $0.10^{\circ}$ resolution 1983-2014 NOAA Climate Prediction Center African Rainfall Climatology Version 2.0 dataset (ARC2; Novella and Thiaw 2013) are utilized.

The analysis period is 1982-2013. 1982 is selected as a starting point because several datasets commence in the early 1980s (e.g., NOAA-OI, ISCCP, PATMOSX, ARC2, 
and GODAS), and others begin with 1979. For datasets that don't completely cover the 1982-2013 period (e.g., ORAS3, ORA-S4, ARC2, ISCCP, and PATMOSX), the trends calculated for the shorter period are assumed to be valid for the full 1982-2013 period.

\section{Results}

Figure 1 shows climatological, annual mean SSTs from the NOAA OI observations (Fig. 1a), 4 atmospheric reanalyses (Fig. 1b-e), and 3 ocean reanalyses (Fig. 1f-h). All climatologies exhibit the same large-scale features, with relatively cool SSTs over the open ocean south of $35^{\circ} \mathrm{S}$ and along the South African/Namibian coast associated with the Benguela current upwelling, and relatively warm SSTs in the equatorial Gulf of Guinea and along the Brazilian coast. With the exception of JRA-55 (Fig. 1e), the SST magnitudes are similar, likely indicative of their reliance on the same observational data for some/most years. For example, ERAI uses a succession of data products for SST including the NCEP 2D-Var and NCEP realtime global daily SST analysis (Dee et al. 2011; Kumar et al. 2013), while MERRA, ORA-S3, and ORA-S4 utilize OISST products (Reynolds et al. 2002) on which the NOAA OI SSTs are based. JRA-55 uses the Centennial In Situ Observation-based Estimates of SSTs (COBE; Ishii et al. 2005) which is based on the Kobe Collection, ICOADS release two buoy in situ observation measurements and does not include satellite-derived SST estimates like many of the other products. Thus, the JRA-55 annual mean SST magnitudes are 1-4 K lower than in the other products, as this data product is more independent of the other datasets.

Figure 2 shows linear trends and statistical significance of annual mean SSTs for the same datasets, expressed in units of K per 32 years. Statistical significance is assessed using Zwier's and von Storch's (1995) two-stage table lookup test procedure for small samples which takes into account autocorrelation. Overall, there is good agreement of significant warming, ranging from 0.5 to $1 \mathrm{~K}$ per 32 years, along the Guinean Coast, and from 0.5 to $1.5 \mathrm{~K}$ per 32 years off the Angolan/Namibian Coast. The datasets also agree that there is a warming trend over the open ocean south of $30^{\circ} \mathrm{S}$, however this trend is not found to be significant at the $90 \%$ level in most of the datasets other than NOAA OI.
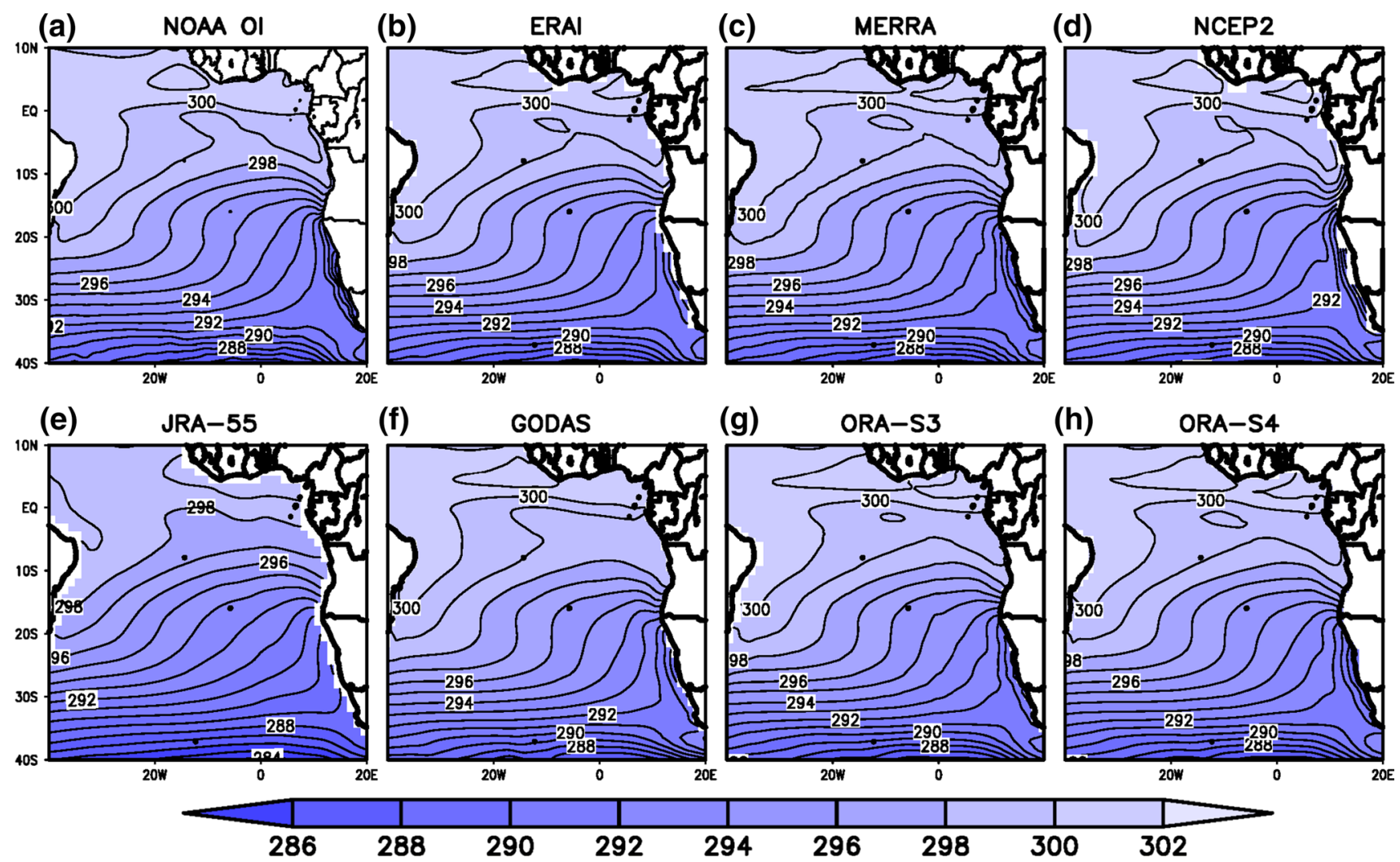

Fig. 1 Climatological annual mean SSTs $(\mathrm{K})$ for the a NOAA OI blended SSTs, the b ERAI, c MERRA, d NCEP2, and e JRA-55 atmospheric reanalyses, and the $\mathbf{f}$ GODAS, $\mathbf{g}$ ECMWF ORA-S3, and h ECMWF ORA-S4 ocean reanalyses. The climatologies for a-f are for $1982-2013, \mathbf{g}$ is for $1982-2011$, and $\mathbf{h}$ is for 1982-2009 

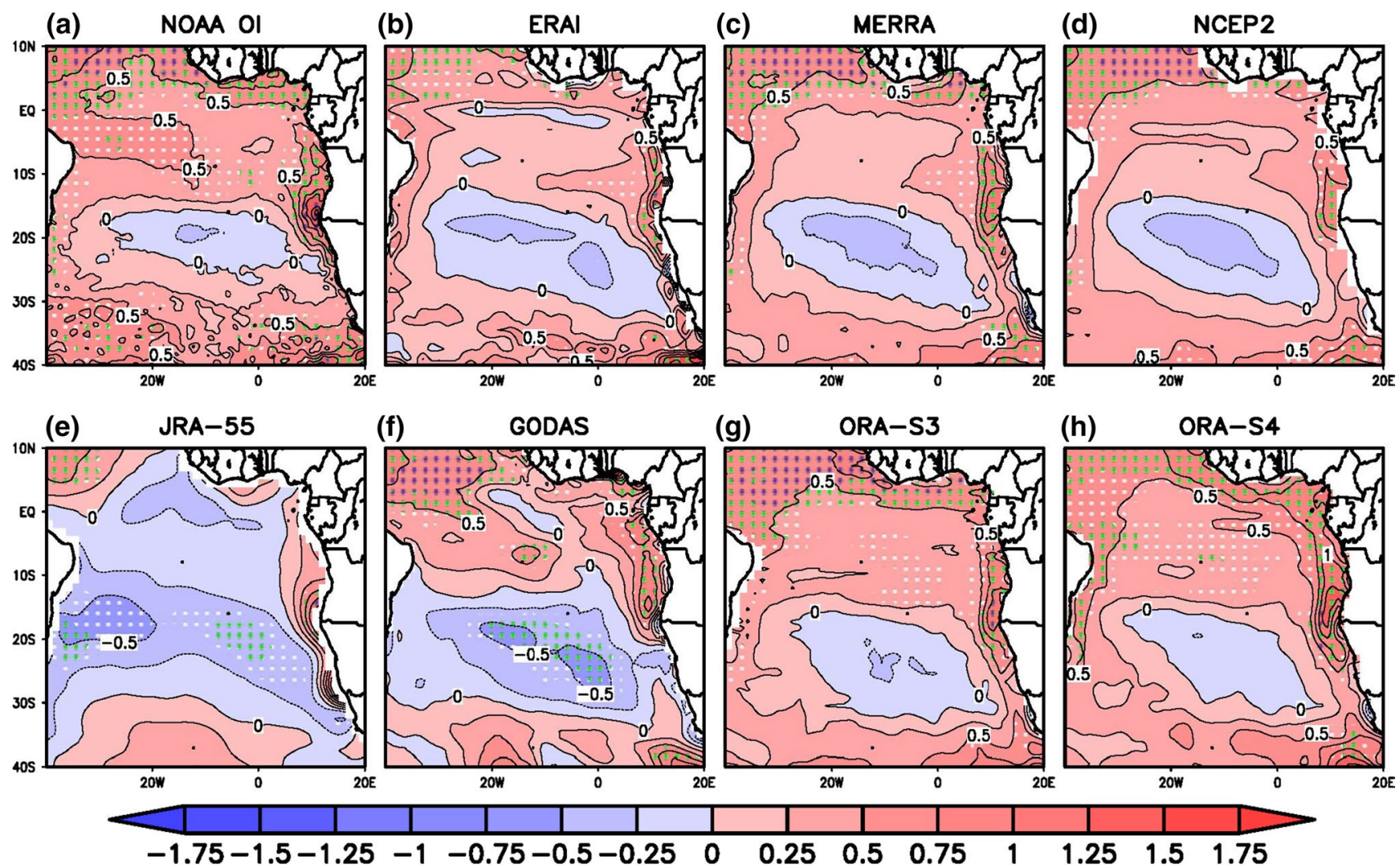

Fig. 2 Linear trend in annual mean SST (K per 32 years) for the a NOAA OI blended SSTs, the b ERAI, c MERRA, d NCEP2, and e JRA-55 atmospheric reanalyses, and the f GODAS, g ECMWF ORA-S3, and h ECMWF ORA-S4 ocean reanalyses. White, green,

All of the datasets also indicate a cooling trend over the open ocean between $18^{\circ} \mathrm{S}$ and $28^{\circ} \mathrm{S}$, ranging between -0.10 and $-0.60 \mathrm{~K}$ per 32 years. This cooling trend is only found to be significant about the $90 \%$ confidence level in JRA-55 (Fig. 2e) and GODAS (Fig. 2f). Note the subtropi$\mathrm{cal} /$ mid-latitude SST trend patterns are consistent with the positive phase pattern of the South Atlantic Subtropical Dipole mode (SASD), a mode of interannual variability over the South Atlantic (Venegas et al. 1997; Haarsma et al. 2005; Morioka et al. 2011, 2012; Nnamchi et al. 2011; Yuan et al. 2014). The SASD positive phase typically lasts about 8 months as it begins developing in austral spring, peaking in intensity in February, then gradually decays in austral fall (Morioka et al. 2012).

Notable differences in SST trends among the datasets also occur. Over the equatorial Atlantic, the SST trend is dataset dependent with NOAA OI, ORA-S3, and ORAS4 indicating a weak warming trend of $0.25-0.5 \mathrm{~K}$ per 32 years, minimal trend in MERRA and NCEP2, and a weak cooling trend of $-0.5 \mathrm{~K}$ per 32 years or less in ERAI, JRA-55, and GODAS. There is also some disagreement along the Brazilian coast as JRA-55 and GODAS indicate a cooling trend, while the other datasets show warming. and purple stippling denotes values found statistically significant at the 90,95 , and $99 \%$ level of confidence, respectively after taking into account autocorrelation using the Zwiers and von Storch (1995) twostage table lookup test procedure

Hovmöller diagrams showing the seasonality of the South Atlantic SST trends in each dataset for three cross-sections are shown in Fig. 3. Figure 3a shows zonal cross sections averaged from $8^{\circ} \mathrm{E}$ to the African coast to examine the strong warming off the Angolan and Namibian coasts (Fig. 2). North of $20^{\circ} \mathrm{S}$, this warming is in place, but not statistically significant, all year in each dataset. While there is some indication of a significant warming trend in August off the Angola coast (i.e., between $15^{\circ} \mathrm{S}$ and $20^{\circ} \mathrm{S}$ ), the most significant warming occurs from mid-October through the middle of January. During these austral summer months, SSTs are estimated to warm by $1-2 \mathrm{~K}$ per 32 years. South of $20^{\circ} \mathrm{S}$, MERRA, NCEP2, ORA-S3, and ORA-S4 indicate a warming trend most of the year, while NOAA OI, ERAI, JRA-55, and GODAS indicating a cooling trend from June to October. Except for GODAS, these trends are not significant.

Figure $3 b$ shows meridional cross sections of monthly linear SST trends averaged between $2^{\circ} \mathrm{N}$ and the Guinean Coast. A warming trend is prevalent year round in most datasets. The exceptions are ERAI, which has a cooling trend of $0.25-0.5 \mathrm{~K}$ per 32 years from May to September, 

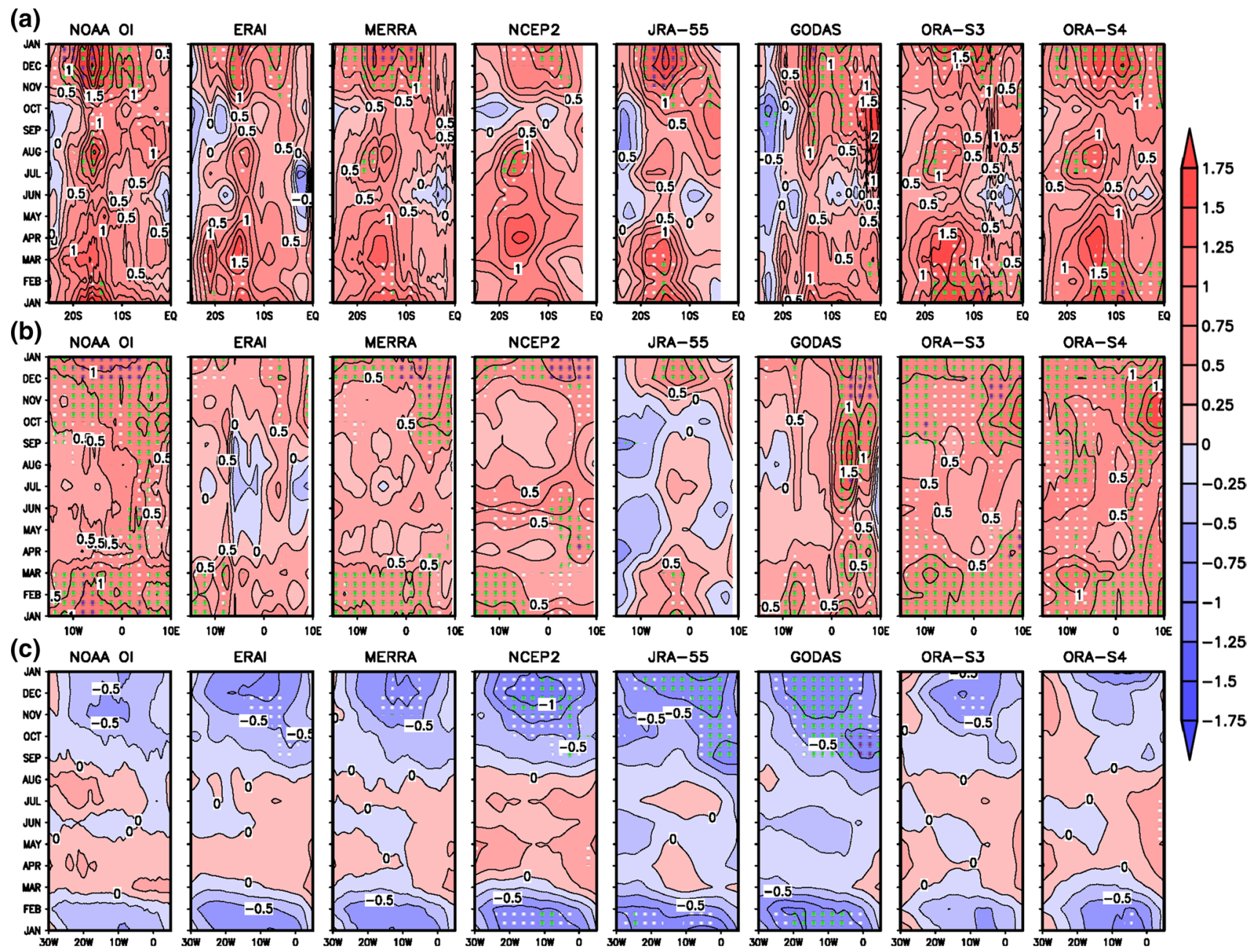

Fig. 3 Monthly linear SST trend (K per 32 years) averaged along the a Angolan/Namibian Coast $\left(8^{\circ} \mathrm{E}-15^{\circ} \mathrm{E}\right)$, b Guinean Coast $\left(2^{\circ} \mathrm{N}-7^{\circ} \mathrm{N}\right)$, and $\mathbf{c}$ the subtropical South Atlantic $\left(18^{\circ} \mathrm{S}-25^{\circ} \mathrm{S}\right)$ for the various datasets (excludes land points in averaging region). White, green, and

purple stippling denotes values found statistically significant at the 90,95 , and $99 \%$ level of confidence, respectively after taking into account autocorrelation

and JRA-55, which has widespread cooling west of $5^{\circ} \mathrm{W}$. The warming trend is significant between November and March. Other times of year also have significant warming, but these instances are dataset dependent. The magnitude of the November-March warming trend varies among the datasets, ranging between 0.5 and $1.5 \mathrm{~K}$ per 32 years.

Figure 3c displays meridional SST cross sections averaged between $18^{\circ} \mathrm{S}$ and $25^{\circ} \mathrm{S}$ over the regional of cooling in the sub-tropical South Atlantic (Fig. 2). The cooling is greatest from September through February when it ranges between 0.25 to over $1 \mathrm{~K}$ per 32 years. Between March and September, there is a weak cooling trend in JRA-55 and GODAS, and a weak warming trend in NOAA OI, ERAI, NCEP2, ORA-S3, and ORA-S4. The September-February cooling trends are significant at least at the $90 \%$ confidence level at some point during September-February in all datasets except for NOAA OI.

Figure 3 indicates that the annual SST trends seen in Fig. 2 occur primarily during austral summer. For this reason, the remainder of this section focusses on the November-January period.

The surface heat budget for the ocean is examined to better understand how the SSTs are maintained and SST trends are established. The net ocean surface heat flux is evaluated using the surface heat balance equation

$C \frac{\partial T_{S}}{\partial t}=S_{\mathrm{ABS}}+\mathrm{LW}_{\text {down }}-\mathrm{LW}_{\mathrm{up}}-H_{\mathrm{S}}-H_{\mathrm{L}}-F_{\mathrm{H}}-F_{\mathrm{V}}-D$,

where $T_{\mathrm{S}}$ is ocean mixed layer temperature and $C$ is the heat capacity of the surface. The ocean surface is warmed by 

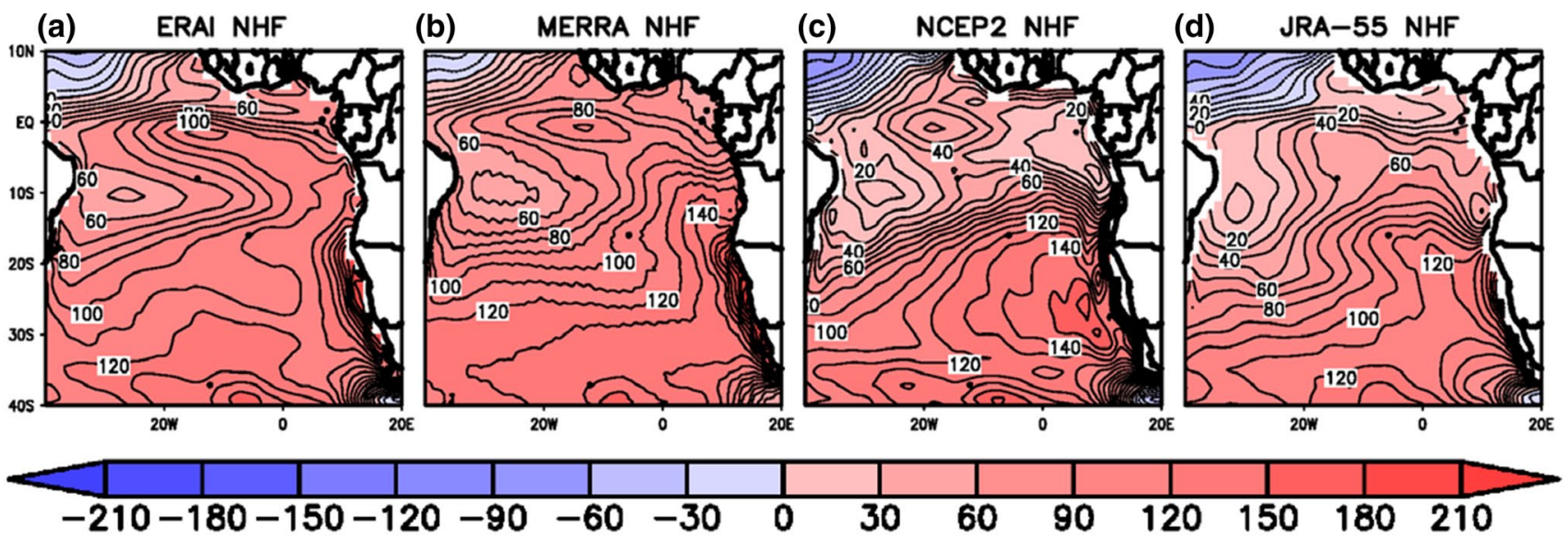

(e) ERAI NHF Trend

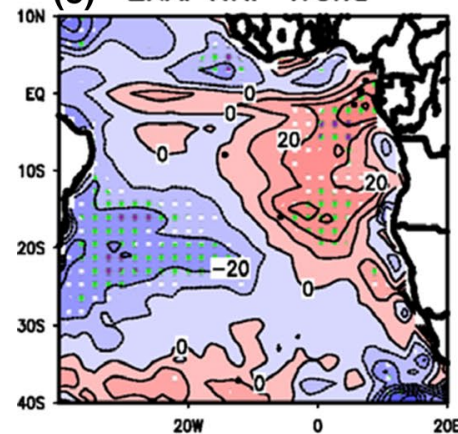

(f) MERRA NHF Trend
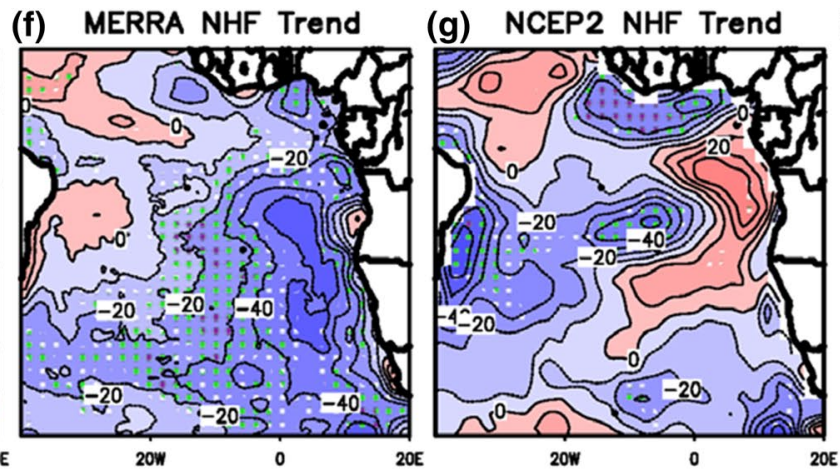

(h) JRA-55 NHF Trend

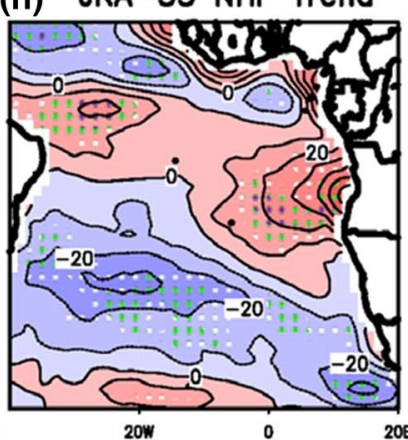

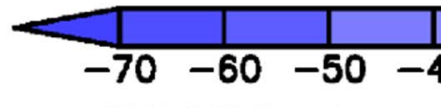

(i) ERAI SST Trend

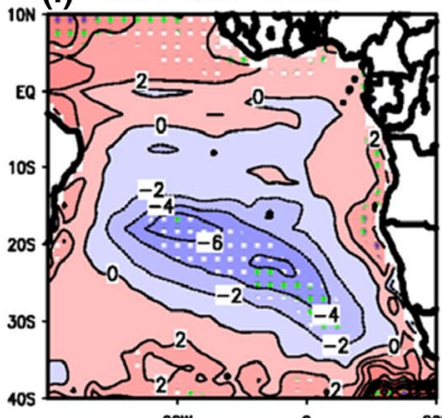

(j) MERRA SST Trend

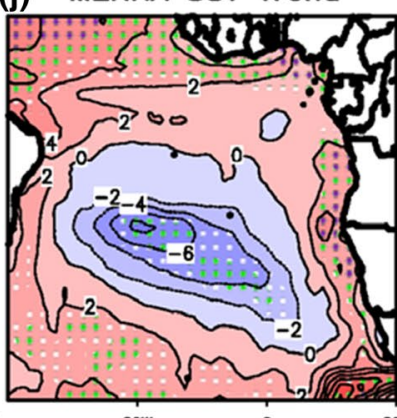

(k) NCEP2 SST Trend

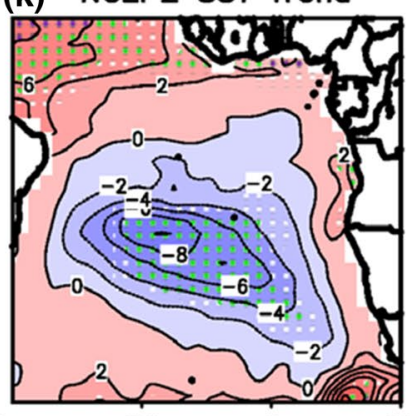

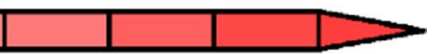

$\begin{array}{llll}40 & 50 & 60 & 70\end{array}$
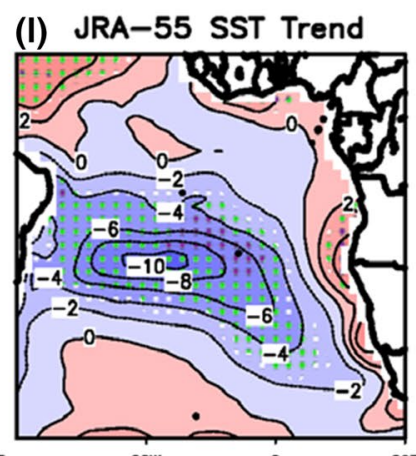

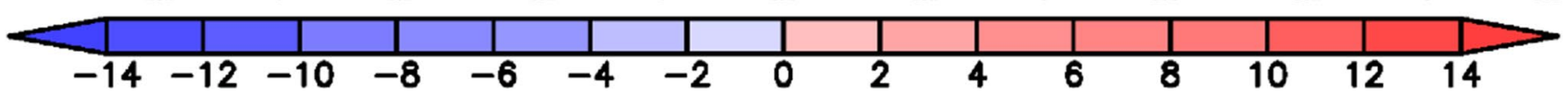

Fig. 4 (Top row) 1982-2013 November-January net surface heat flux (NHF) from the atmosphere $\left(\mathrm{W} \mathrm{m}^{-2}\right.$ ) for the a ERAI, b MERRA, c NCEP2, and d JRA-55 reanalysis climatologies. (Middle row) 1982-2013 November-January trends in net surface heat flux from the atmosphere ( $\mathrm{W} \mathrm{m}^{-2}$ per 32 years) for the e ERAI, f MERRA, g NCEP2, and h JRA-55 reanalyses. (Bottom row) 1982-2013
November-January heat flux trend inferred from the observed temperature trends using Eq. 3 ( $\mathrm{W} \mathrm{m}^{-2}$ per 32 years) for the i ERAI, j MERRA, k NCEP2, and I JRA-55 reanalyses. White, green, and purple stippling denotes values found statistically significant at the 90,95 , and $99 \%$ level of confidence, respectively after taking into account autocorrelation the absorption of solar radiation $\left(S_{\mathrm{ABS}}\right)$ and longwave back radiation $\left(\mathrm{LW}_{\mathrm{down}}\right)$, and cooled by the emission of longwave radiation from the surface $\left(\mathrm{LW}_{\mathrm{up}}\right)$, which is related to $T_{\mathrm{s}}$ by:

$\mathrm{LW}_{\text {up }}=\varepsilon \sigma T_{\mathrm{s}}^{4}$, where $\varepsilon$ is the longwave emissivity of the surface and $\sigma$ is the Stefan-Boltzmann constant. $H_{\mathrm{S}}$ and $H_{\mathrm{L}}$ are the sensible and latent heat fluxes from the surface to the atmosphere, respectively. The final three terms in Eq. 1 represent the horizontal redistribution of heat in the upper ocean by 
mixed layer currents $\left(F_{\mathrm{H}}\right)$, the vertical redistribution of heat $\left(F_{\mathrm{V}}\right)$, and diffusion $(D)$. The first five terms on the RHS of Eq. 1 are standard output from the atmospheric reanalyses, while $F_{\mathrm{H}}, F_{\mathrm{V}}$, and $D$ can be estimated from the available ocean reanalyses.

Figure 4a-d show the 1982-2013 climatological November-January seasonal net heat flux associated with the first five terms on the RHS of Eq. 1 from each atmospheric reanalysis; positive values indicate heat added into the ocean surface. Heat fluxes are not shown for the ocean reanalyses because they are forced with the net heat flux from atmospheric reanalyses, and do not calculate it internally. GODAS uses NCEP2 daily heat fluxes, while ORAS3 and ORA-S4 utilize the ERA-40, ECMWF operational, and/or ERAI reanalyses.

There is a net flux of heat from the atmosphere into the ocean during austral summer over much of the equatorial and subtropical South Atlantic Ocean. The strongest net heating occurs along the Namibian/South African coast in the vicinity of the cold upwelling region of the Benguela current (Fig. 1). There is also strong heating over the equatorial Atlantic upwelling region, with larger heating rates in ERAI and MERRA ( $\left.~ 80-110 \mathrm{~W} \mathrm{~m}^{-2}\right)$ compared to NCEP2 and JRA$55\left(\sim 40-60 \mathrm{~W} \mathrm{~m}^{-2}\right)$. All of the reanalyses indicate a relative minimum in net surface heating off the Brazilian coast near $10^{\circ} \mathrm{S}$, but the magnitude varies among the datasets.

Figure $4 \mathrm{e}-\mathrm{h}$ show the net heat flux trends associated with the first five terms on the RHS of Eq. 1 from the atmospheric reanalyses for austral summer (November-January). ERAI, NCEP2, and JRA-55 show significant increases in the heat flux from the atmosphere of $10-50 \mathrm{~W} \mathrm{~m}^{-2}$ per 32 years over the eastern South Atlantic between the equator and $20^{\circ} \mathrm{S}$, although the spatial extent differs somewhat among the reanalyses. (MERRA is discussed below). Cooling trends $\left(\sim 10-30 \mathrm{~W} \mathrm{~m}^{-2}\right.$ per 32 years) over the open ocean between $25^{\circ} \mathrm{S}$ and $35^{\circ} \mathrm{S}$, adjacent to the Brazilian coast $\left(\sim 10-50 \mathrm{~W} \mathrm{~m}^{-2}\right.$ per 32 years), and along the Guinean coast $\left(\sim 10-30 \mathrm{~W} \mathrm{~m}^{-2}\right.$ per 32 years) occur in all four reanalyses. Over the central equatorial Atlantic, ERAI and JRA55 show a weak warming trend while NCEP2 and MERRA indicate a weak cooling trend.

The November-January net heat flux trends in MERRA (Fig. 4f) are different from the other three reanalyses, especially over the eastern South Atlantic. These differences are possibly related to observing system changes in MERRA. Beginning in 1998, NOAA-15 Advanced Microwave Sounding Unit-A (AMSU-A) radiances were incorporated into the MERRA assimilation processes. This change caused a discontinuity in the atmospheric moisture time series that adversely impacted the surface radiation balance (Bosilovich et al. 2011; Rienecker et al. 2011; Robertson et al. 2011). ERAI also incorporates AMSU-A data, but does not assimilate the 1-3 and 15 window channels, and
Fig. 5 Components of the surface radiation budget for the 19822013 austral summer climatology for the a-e ERAI, $\mathbf{f}-\mathbf{j}$ NCEP2, and k-o JRA-55 reanalyses. Units are $\mathrm{W} \mathrm{m}^{-2}$ and positive (negative) values denote a heat flux into (out of) the ocean surface

does not have the discontinuity. Since we cannot properly evaluate 1982-2013 trends using MERRA, it is dropped from subsequent analysis after Fig. 4.

To place the net heat flux trends in better context, they are compared with estimates of the heat flux inferred from the observed temperature trend $\left(H_{\mathrm{SST}}\right)$. Figure $4 \mathrm{i}-1$ show austral summer estimates $H_{\mathrm{SST}}$ for the same four atmospheric reanalyses estimated by:

$H_{\mathrm{SST}}\left(\mathrm{W} \mathrm{m}^{-2}\right)=\rho_{\mathrm{w}} c_{\mathrm{w}} h \frac{\partial T_{\mathrm{s}}}{\partial t}$,

where $\rho_{\mathrm{w}}$ is the density of water $\left(\sim 1000 \mathrm{~kg} \mathrm{~m}^{-3}\right), \mathrm{c}_{\mathrm{w}}$ is the specific heat capacity of water $\left(\sim 218 \mathrm{~J} \mathrm{~kg}^{-1} \mathrm{~K}^{-1}\right), h$ is the mixed layer depth, and $T_{\mathrm{S}}$ is the SST. $\partial T_{\mathrm{S}} / \partial t$ is estimated from the surface temperature from each reanalysis. Values for $h$ need to be obtained from the ocean reanalyses since the atmospheric reanalyses do not provide an estimate for this field. Only two of the ocean reanalyses analyzed, GODAS and ORA-S3, provide values for $h$ and are considered for use here. Figure $4 \mathrm{i}-1$ show the values of HSST using $h$ from GODAS. GODAS was selected for use because it has a higher spatial resolution than ORAS3 meaning that $h$ is more realistically resolved especially near the African coast, and the GODAS time series spans the entire 1982-2013 period whereas ORA-S3 only cover 1982-2011. Note that the shading interval scale applied in Fig. 4i-1 differs from the scale used in Fig. 4e-h, as the magnitudes are generally smaller for $\mathrm{H}_{\mathrm{SST}}$.

Along the Angolan/Namibian and Guinean coasts $H_{\mathrm{SST}}$ is approximately $2-8$ and $2-4 \mathrm{~W} \mathrm{~m}^{-2}$ per 32 years, respectively. In the case of the former, the net heat flux trends from the reanalyses range from 10 to $60 \mathrm{~W} \mathrm{~m}^{-2}$ per 32 years depending on the reanalysis. For the latter, the sign of the net heat flux trend is generally negative, suggesting that it may not be directly responsible for explaining the warming trend here. Over the subtropical South Atlantic $H_{\mathrm{SST}}$ is negative, ranging between -2 and $-12 \mathrm{~W} \mathrm{~m}^{-2}$ per 32 years depending on the reanalysis. This is consistent with the general sign for the net heat flux trends in Fig. 4e, $\mathrm{f}$ and $\mathrm{h}$, though the magnitudes appear to be smaller for $H_{\text {SST }}$ for some regions.

To test the sensitivity of the results on the selection of $h$ the calculation is repeated using $h$ obtained from ORA-S3. Results from this analysis (not shown) indicate that over the open ocean the SST trends generally fall within the intrareanalysis range shown in Fig. 4i-1. There are larger differences along the African coast as SST warming trends are almost double those shown in Fig. 4i-l. This difference is associated with the mixed-layer depth being unrealistically 

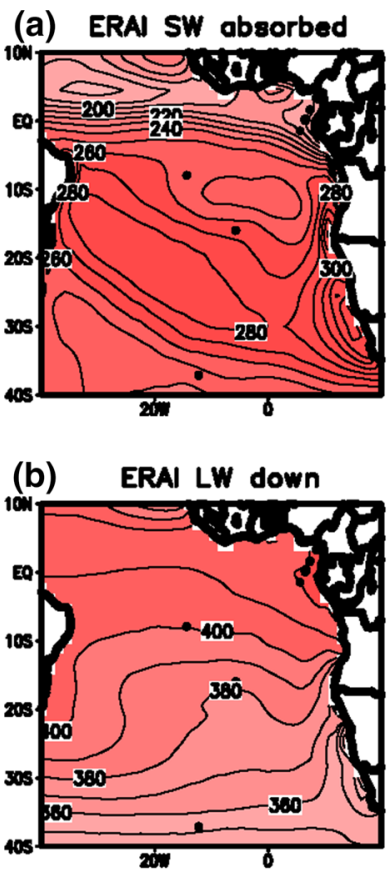

(c) ERA LW up

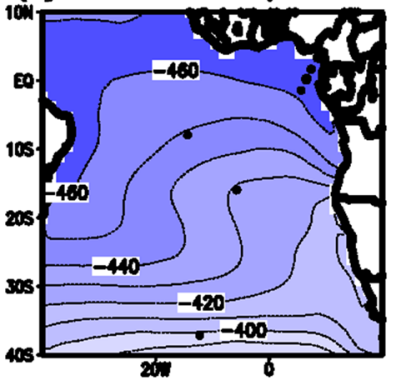

(d) ERAI Lotent Heat

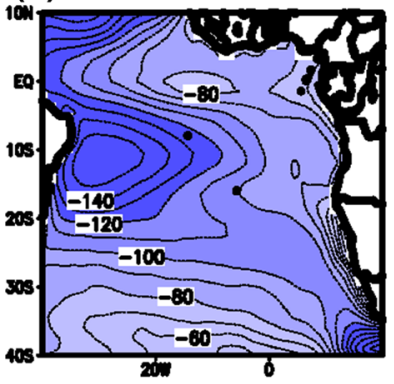

(e) ERA Sensible Hoot

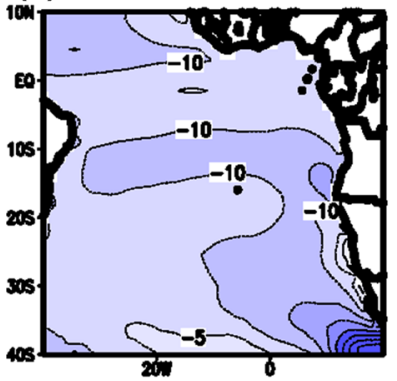

(f) NCEP2 SW absorbed

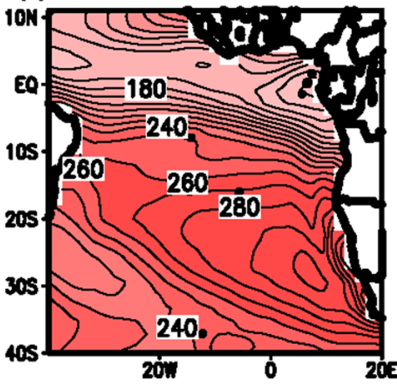

(g) NCEP2 LW down

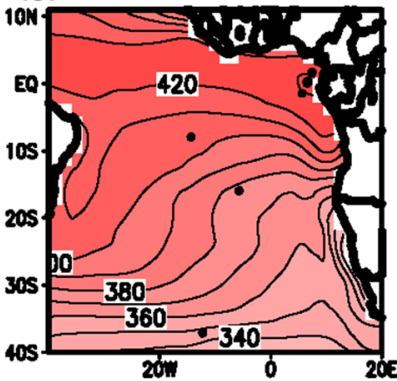

(h) NCEP2 LW up

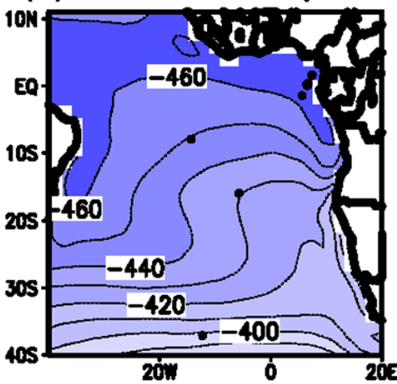

(i) NCEP2 Latent Heat

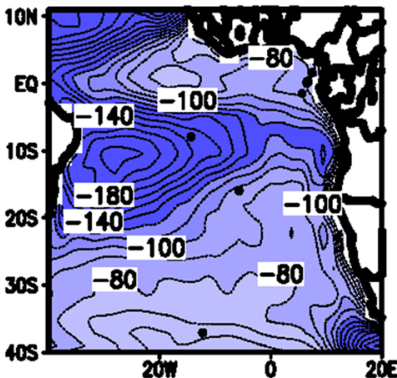

(j) NCEP2 Sensible Heat

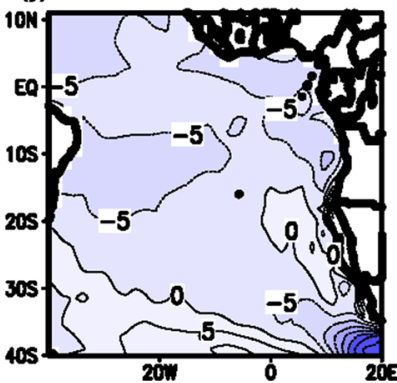

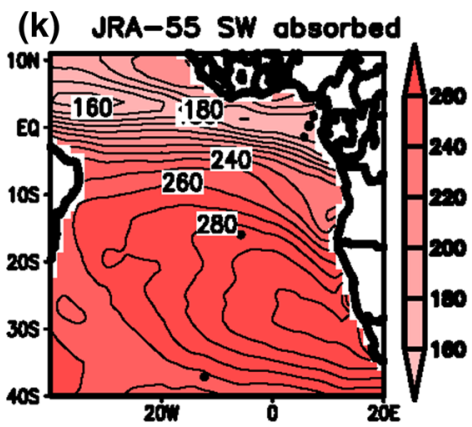
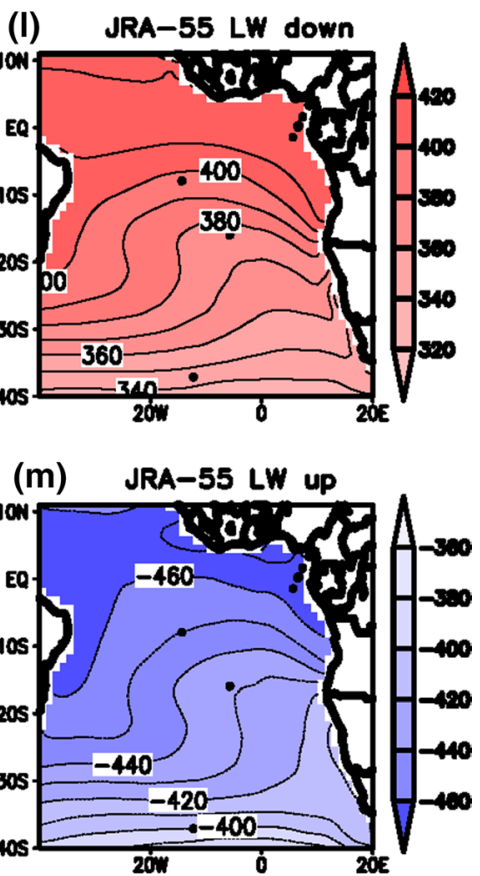

(n) JRA-55 Lotent Heot

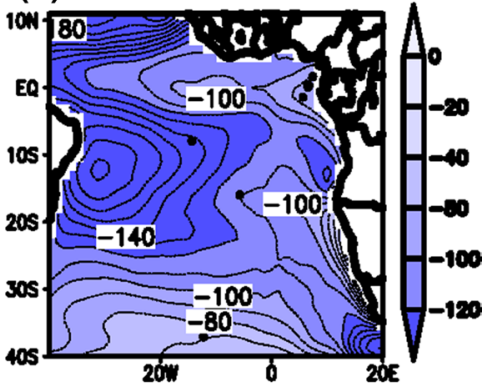

(0) JRA-55 Sensible Heat

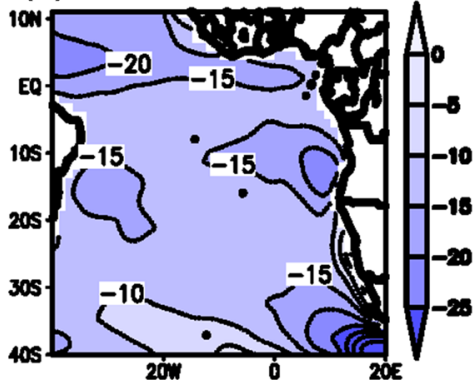


deep near the African coast in ORA-S3. For example, the climatological November-January mixed layer depths off the Gabon and Guinean coasts range between 10 and $15 \mathrm{~m}$ in GODAS, but are greater than $30 \mathrm{~m}$ in ORA-S3. Climatological observational estimates such as those from the Naval Research Laboratory dataset (Kara et al. 2003) indicate that GODAS is more realistic.

Figure 5 shows the climatological November-January values for each of the first five terms on the RHS of Eq. 1 for ERAI (Fig. 5a-e), NCEP2 (Fig. 5f-j), and JRA-55 (Fig. 5k-o). The largest positive shortwave absorbed $\left(S_{\mathrm{ABS}}\right)$ fluxes occur off the Namibian coast and extend northwestward across the sub-tropical South Atlantic in the approximate location of the bulge of relatively warmer SSTs (Fig. 1). Over the equatorial Atlantic and north of the equator, positive $S_{\mathrm{ABS}}$ values are lower, reflecting the location of the austral summer position of the marine ITCZ. The overall pattern is similar among the three datasets. There is also good agreement among the reanalyses for the downward longwave flux ( $\mathrm{LW}_{\text {down }}$; Fig. 5b, g, l) and upward longwave flux $\left(\mathrm{LW}_{\text {up }}\right.$; Fig. 5c, h, m). Latent heat flux, $H_{\mathrm{L}}$ (Fig. 5d, $\mathrm{i}, \mathrm{n})$ terms are also in relatively good agreement over the open ocean, but show distinct differences near the coastal regions, possibly related to coastal wind differences. Conversely, sensible heat fluxes $\left(H_{\mathrm{S}}\right)$ are not very consistent in the three reanalyses (Fig. 5e, j, o), but they are small relative to the other four terms.

Figure 6 shows the November-January trends for each of the atmospheric heat flux terms for the ERAI (Fig. 6ae), NCEP2 (Fig. 6f-j), and JRA-55 (Fig. 6k-o) reanalysis climatologies. While there is general agreement among the reanalyses in the trends in the total net surface heat flux from the atmosphere (Fig. 4e, g, h), how this trend is established varies among the datasets. In general, the reanalyses are in reasonable agreement for the longwave components of the surface heat balance and the sensible heat flux, but they produce large differences in the shortwave radiation absorbed and the latent heat flux.

Over the region of positive SST trends in the southeastern Atlantic (east of $5^{\circ} \mathrm{W}$ between $10^{\circ} \mathrm{S}$ and $20^{\circ} \mathrm{S}$; Fig. 2), ERAI (Fig. 6a) and NCEP2 (Fig. 6f) place positive trends in $\mathrm{SW}_{\mathrm{ABS}}$, ranging from around $10-20 \mathrm{~W} \mathrm{~m}^{-2}$ per 32 years for ERAI and $30-40 \mathrm{~W} \mathrm{~m}^{-2}$ per 32 years for NCEP2. Trends in $\mathrm{LW}_{\text {up }}$ (Fig. 6c, h), and $H_{\mathrm{S}}$ (Fig. 6e, j) are also similar between these two reanalyses and relatively small (i.e., within $\pm 5 \mathrm{~W} \mathrm{~m}^{-2}$ per 32 years). $\mathrm{LW}_{\text {down }}$ trend is also small in ERAI (Fig. 6b), but negative $\left(\sim 5-15 \mathrm{~W} \mathrm{~m}^{-2}\right.$ per 32 years) in NCEP2 (Fig. $6 \mathrm{~g}$ ). The largest difference between these two reanalyses is in the $H_{\mathrm{L}}$ trends, with ERAI (Fig. 6d) producing a positive trend of $5-15 \mathrm{~W} \mathrm{~m}^{-2}$ per 32 years while NCEP2 (Fig. 6i) has a negative trend of $5-20 \mathrm{~W} \mathrm{~m}^{-2}$ per 32 years. Thus, in NCEP2, the larger positive trend in the solar radiation absorbed is primarily offset
Fig. 6 1982-2013 austral summer trends in components of the surface radiation budget for the a-e ERAI, $\mathbf{f}-\mathbf{j}$ NCEP2, and $\mathbf{k}-\mathbf{o}$ JRA55 reanalyses. Units are $\mathrm{W} \mathrm{m}^{-2}$ per 32 years and white, green, and purple stippling denotes values found statistically significant at the 90, 95, and $99 \%$ level of confidence, respectively after taking into account autocorrelation

by an increase in the sensible heat loss to the atmosphere and, to a lesser extent, a larger decrease in evaporation. In contrast to ERAI and NCEP2, the $\mathrm{SW}_{\mathrm{ABS}}$ trend in JRA55 (Fig. 6k) is negative over this same region. The warming trend is instead associated with positive trends in $H_{\mathrm{L}}$ (Fig. 6n), and to a lesser extent positive trends in $\mathrm{LW}_{\text {down }}$ (Fig. 61) and $H_{\mathrm{S}}$ (Fig. 6o).

Over the subtropical South Atlantic between $20^{\circ} \mathrm{S}$ and $30^{\circ} \mathrm{S}$, where a cooling trend occurs in the reanalyses between $20^{\circ} \mathrm{S}$ and $30^{\circ} \mathrm{S}$ (Fig. 2), all three datasets indicate a robust negative $H_{\mathrm{L}}$ trend in some form (i.e., increased latent heat loss from the ocean surface). When thinking about the bulk formulae of $H_{\mathrm{L}}$ both the surface wind speed and the difference between the surface specific humidity $\left(q_{s}\right)$ and the near surface specific humidity $\left(q_{a}\right)$ need to be considered. For example, Fig. 7a-d show the austral summer ERAI climatological mean values for $q_{s}, q_{a}$, the $q_{s}-q_{a}$ difference, and the $10-\mathrm{m}$ wind speed (Wspd), while Fig. 7e-h show their trends. Examination of the trends in $q_{s}, q_{a}$, and the surface wind speed over the subtropical South Atlantic reveal a negative trend is both $q_{s}$ and $q_{a}$ (i.e., a decrease in both $q_{s}$ and $q_{a}$ ), however $q_{a}$ decreases at a faster rate than $q_{s}$. This means that the trend in difference between the surface specific humidity and the near surface specific humidity is positive (Fig. $7 \mathrm{~g}$ ), while the trend in the wind speed is also positive leading to the increase in latent heat flux loss from the ocean. Similar trends are also observed in JRA-55 and NCEP2 (not shown), though the trends in the $q_{s}-q_{a}$ difference are much smaller in NCEP2 as the difference in $q_{\mathrm{s}}$ and $q_{a}$ is not as large. A negative trend in $\mathrm{LW}_{\text {down }}$ is also contributing, but the trend magnitudes are about half the size of the $H_{\mathrm{L}}$ trend magnitudes. The trend in $\mathrm{LW}_{\text {up }}$ is consistent with the change in the SST (see Eq. 2). A negative $\mathrm{SW}_{\mathrm{ABS}}$ trend west of $10^{\circ} \mathrm{W}$ and a positive $\mathrm{SW}_{\mathrm{ABS}}$ trend east of $10^{\circ} \mathrm{W}$ pattern is identifiable in all three datasets, though the magnitudes vary considerably among the reanalyses.

Along the Guinean Coast the negative trend in the net atmospheric heat flux (Fig. 4) is associated with a negative trend in $\mathrm{SW}_{\mathrm{ABS}}$ in all three datasets. The magnitude of the negative $\mathrm{SW}_{\mathrm{ABS}}$ trends in ERAI and JRA-55 are comparable, around $5-15 \mathrm{~W} \mathrm{~m}^{-2}$ per 32 years, but larger in NCEP2 (5-15 $\mathrm{W} \mathrm{m}^{-2}$ per 32 years). The larger negative $\mathrm{SW}_{\mathrm{ABS}}$ trend in NCEP2 is associated with a negative trend in $H_{\mathrm{L}}$, unlike the other two reanalyses, which suggest either a weak $H_{\mathrm{L}}$ trend in ERAI, or a positive $H_{\mathrm{L}}$ trend in JRA-55. 
(a) ERAI SW absorbed

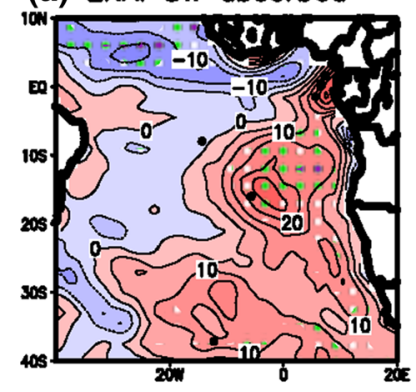

(b) ERAI LW down

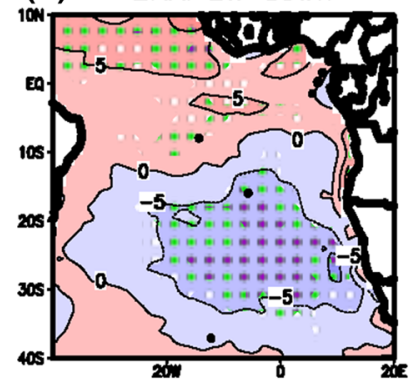

(c) ERA LW Up

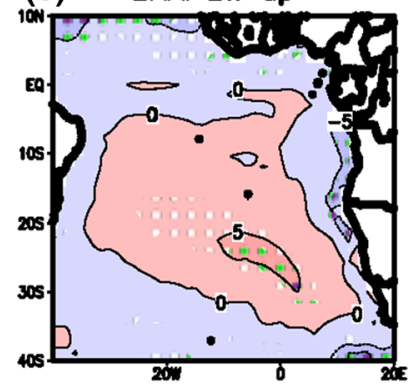

(d) ERAI Latent Hoat

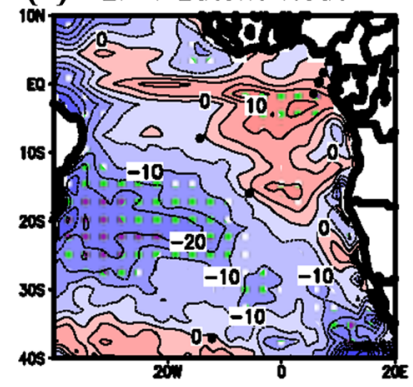

(e) ERAN Sensible Heat

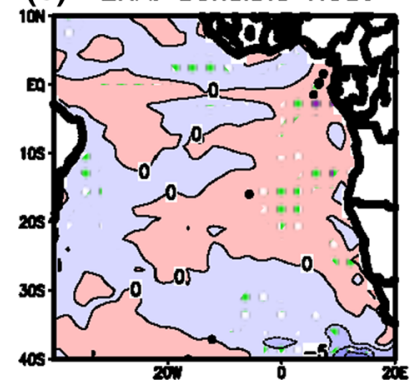

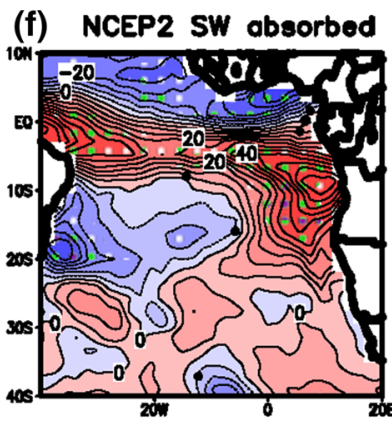

(g) NCEP2 LW down

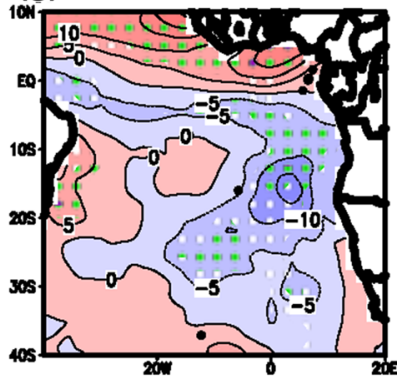

(h) NCEP2 LW Up

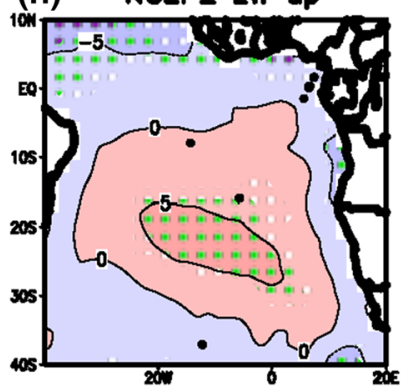

(i) NCEP2 Latent Hoat

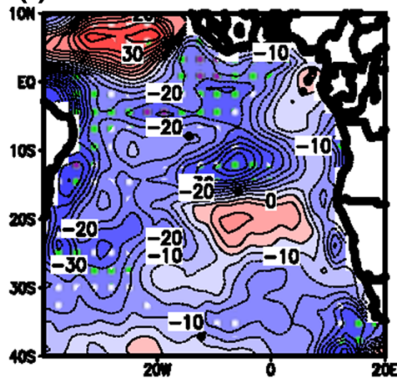

(j) NCEP2 Sensible Heat

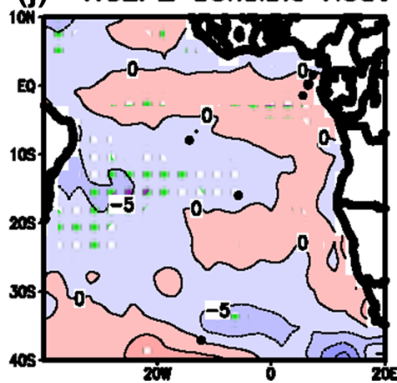

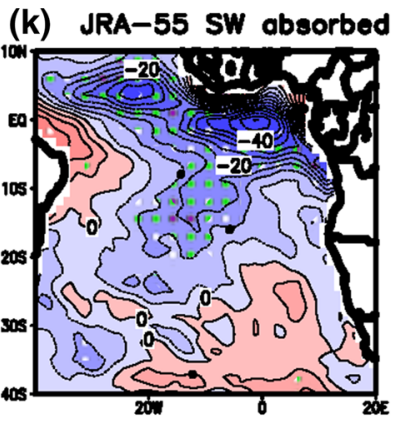

(I) JRA-55 LW down
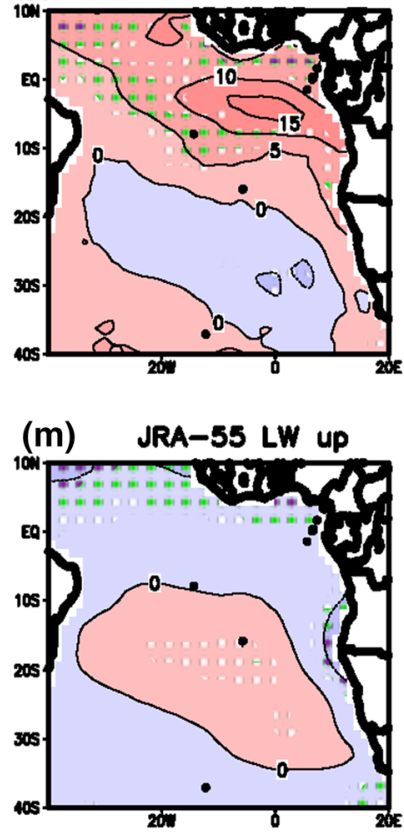

(n) JRA-55 Lotent Heat
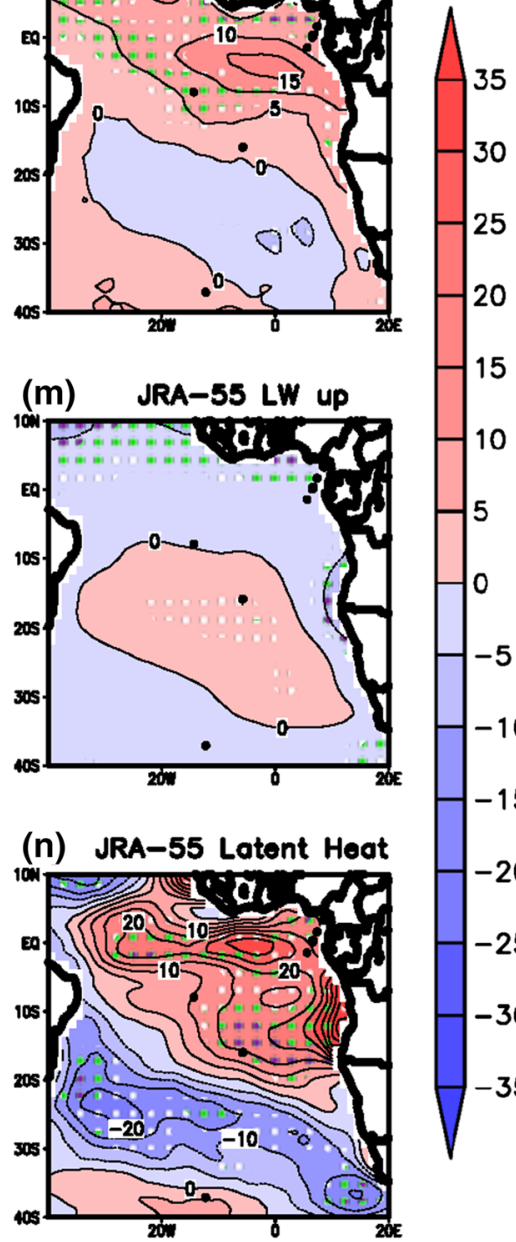

35 30 25 20 15 10 5

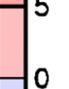

0 $-5$ $-10$ $-15$ $-20$ $-25$ $-30$ $-35$

(o) JRA-55 Sensible Heot

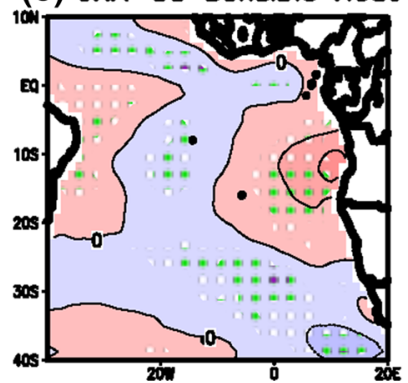




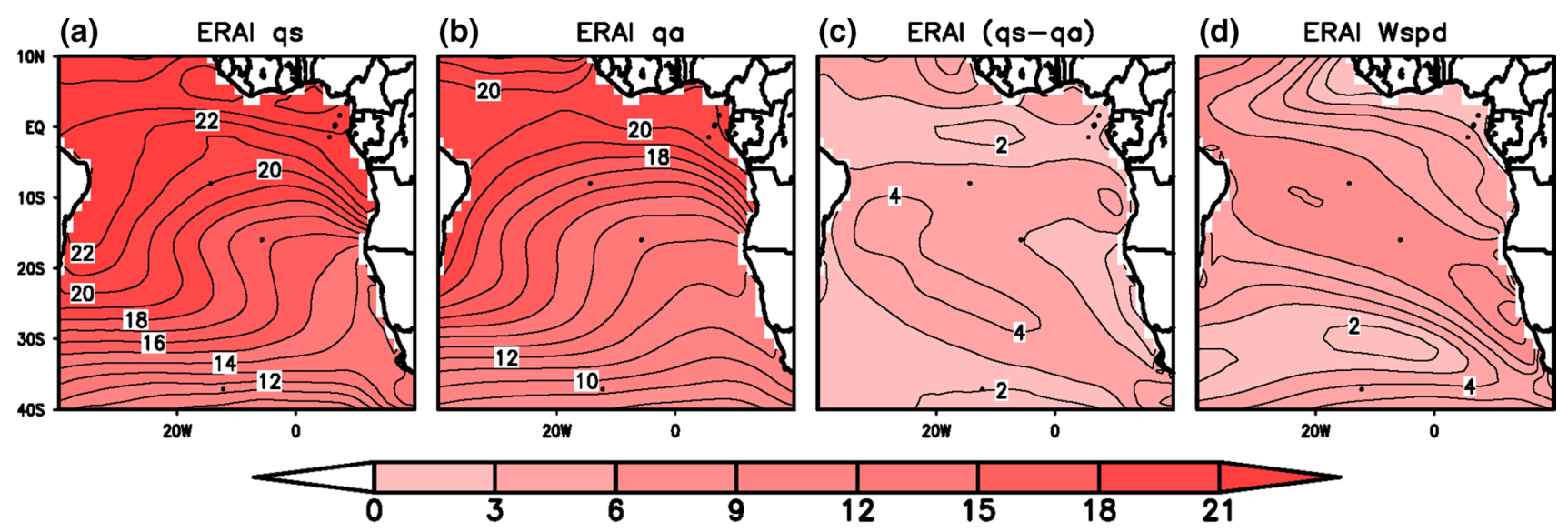

(e) ERAI qs Trend

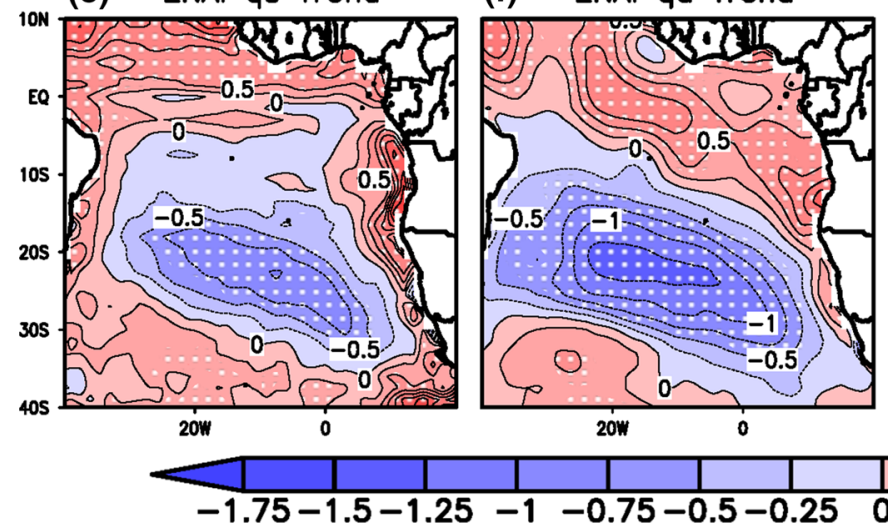

(g) ERAl (qs-qa) Trend

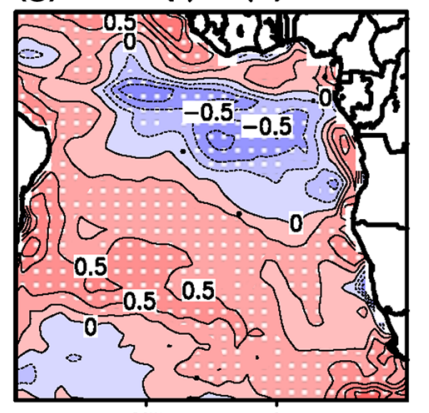

(h) ERAI Wspd Trend

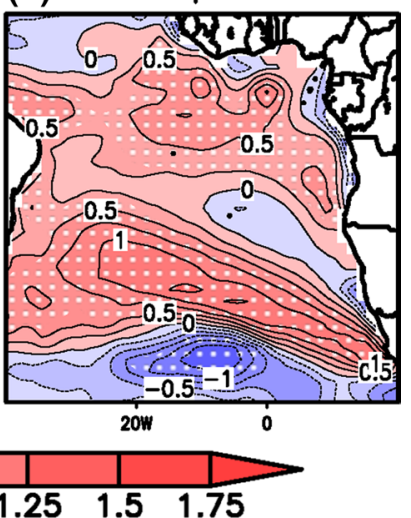

Fig. 7 (Top row) ERAI 1982-2013 November-January climatological mean a surface specific humidity $q s\left(\mathrm{~g} \mathrm{~kg}^{-1}\right)$, b $2-\mathrm{m}$ specific humidity $q a\left(\mathrm{~g} \mathrm{~kg}^{-1}\right)$, $\mathbf{c} q s-q a$ difference $\left(\mathrm{g} \mathrm{kg}^{-1}\right)$, and $\mathbf{d} 10-\mathrm{m}$ wind speed $\left(\mathrm{m} \mathrm{s}^{-1}\right)$. (Bottom row) ERAI 1982-2013 November-January

Cloud cover trends are also evaluated since cloud cover can play an important role in affecting the surface heat balance. Figure 8a-e show the climatological NovemberJanuary total cloud cover from ISCCP and PATMOSX observations and the three atmospheric reanalyses, while Fig. $8 \mathrm{f}-\mathrm{j}$ show the total cloud cover trends for the same datasets. The ISCCP (Fig. 8a) and PATMOSX (Fig. 8b) climatologies are in good agreement, with large cloud fractions (i.e., $>80 \%$ ) off the Angolan coast centered at $18^{\circ} \mathrm{S}$, over the equatorial North Atlantic west of $20^{\circ} \mathrm{W}$, and near $40^{\circ} \mathrm{S}$, and low cloud fractions (i.e., $<60 \%$ ) over the equatorial South Atlantic west of $20^{\circ} \mathrm{W}$ centered near $8^{\circ} \mathrm{S}$, along an axis extending from $8^{\circ} \mathrm{S} ; 30^{\circ} \mathrm{W}$ to about $30^{\circ} \mathrm{S} ; 10^{\circ} \mathrm{W}$, and along the Namibian/South African coast over the Benguela current. This pattern is similar in the ERAI reanalysis (Fig. 8c), but not in NCEP2 (Fig. 8d) and JRA-55 (Fig. 8e). For example, the NCEP2 cloud fraction pattern over the subtropical Atlantic is opposite to the observations, with large cloud fractions in the west of the basin and low fractions in the east. The JRA-55 pattern is closer to the trends in a $q s\left(\mathrm{~g} \mathrm{~kg}^{-1}\right.$ per 32 years), b $q a\left(\mathrm{~g} \mathrm{~kg}^{-1}\right.$ per 32 years), c $q s-q a$ difference $\left(\mathrm{g} \mathrm{kg}^{-1}\right.$ per 32 years), and $\mathbf{d} 10-\mathrm{m}$ wind speed $\left(\mathrm{m} \mathrm{s}^{-1}\right.$ per 32 years). Stippling denotes values found statistically significant at the $90 \%$ level of confidence

observations than NCEP2, although magnitudes are lower compared to ISCCP and PATMOSX over many regions.

Cloud cover trends for ISCCP (Fig. 8f) and PATMOSX (Fig. 8g) suggest a negative trend (i.e., less cloud cover) for much of the South Atlantic. For the most part these changes are not significant, except along the Namibian/South African coast, and over North Atlantic near $10^{\circ} \mathrm{N}$. These two observational datasets are in poor agreement over the equatorial Atlantic, with ISCCP indicating a negative trend, and PATMOSX a positive trend. Likewise PATMOSX indicates a more robust negative trend centered at $25^{\circ} \mathrm{S} ; 5^{\circ} \mathrm{W}$, which is only hinted at in ISCCP.

Cloud cover trends in the reanalyses vary considerably. ERAI (Fig. 8h) has negative trends south of $10^{\circ} \mathrm{S}$, and positive trends over the equatorial Atlantic. A significant negative trend is clearly identifiable over the Benguela current, but the magnitudes and the spatial extent of this feature are much larger than the observations. NCEP2 (Fig. 8i) does not capture this negative trend off the Namibian coast. Furthermore, negative trends are located over the 
Fig. 8 (Left column) November-January climatological total cloud cover (\%) from a ISCCP, b AVHRR PATMOSX, c ERAI, d NCEP2, and e JRA-55 datasets. (Right column) NovemberJanuary linear trends in total cloud cover (\% per 32 years) from $\mathbf{f}$ ISCCP, $\mathbf{g}$ AVHRR PATMOSX, h ERAI, i NCEP2, and j JRA-55 datasets. White, green, and purple stippling denotes values found statistically significant at the 90,95 , and $99 \%$ level of confidence, respectively after taking into account autocorrelation
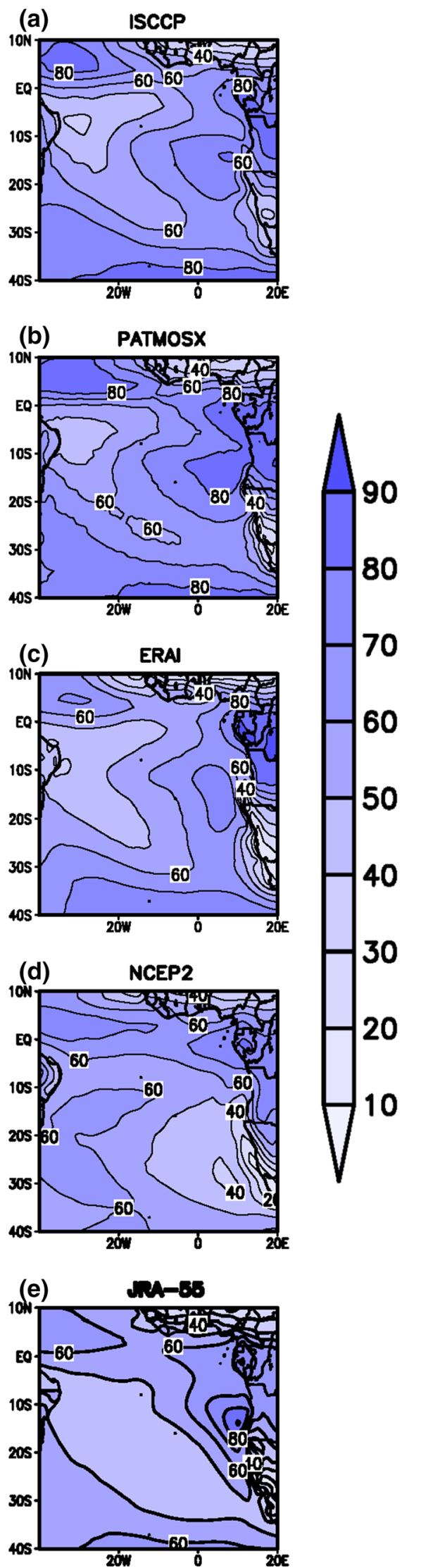

10

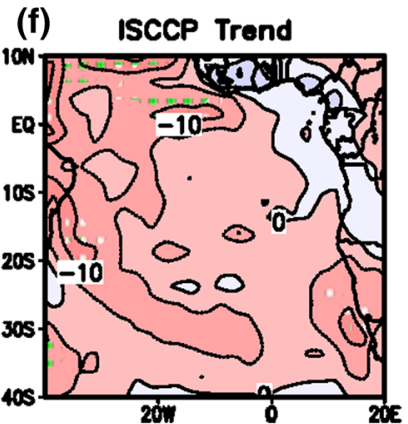

(g) PATMOSX Trend
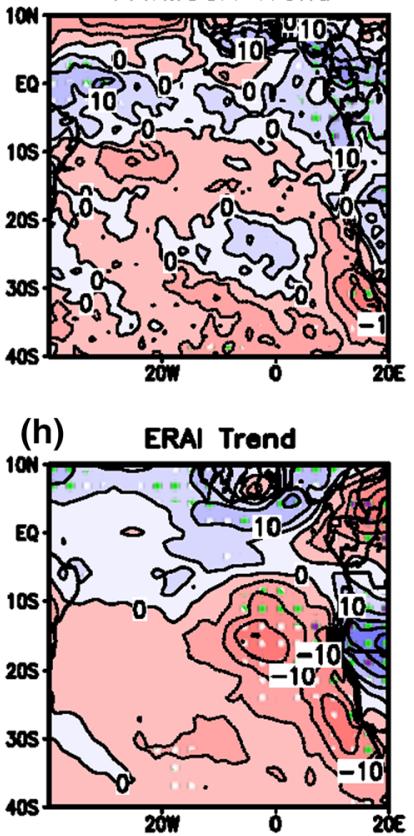

10

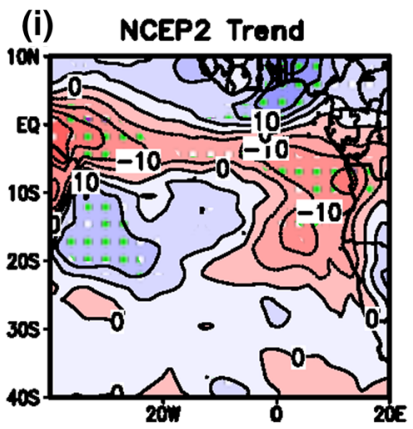

$-10$

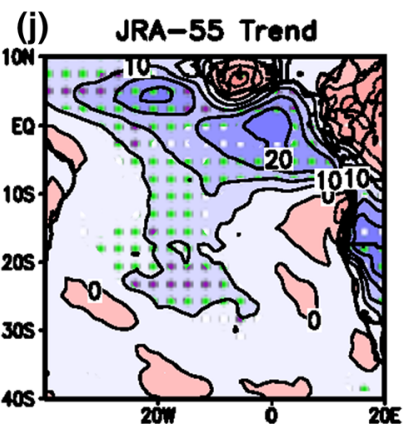


equatorial South Atlantic and along the Angola coast in NCEP2, while positive trends are found off the South Atlantic coast of Brazil. Trend patterns are weak in JRA55 (Fig. 8j) outside of the equatorial Atlantic, where they are negative. All three reanalyses indicate significant negative trends along the Guinean Coast, but these are not identifiable in either observational dataset. Since the surface heat balance is sensitive not only to the total cloud amount but also changes in cloud elevation, cloud cover trends for low, middle, and high cloud cover were also examined for the different data products (not shown). The general consensus from this analysis is that the trends in total cloud cover shown in Fig. 8 over the South Atlantic, outside of the equatorial region are primarily associated with changes in low cloud cover due to the decrease in the lower tropospheric specific humidity (e.g., Fig. 7f). Over the equatorial Atlantic, the trends in total cloud cover are found to be associated more with changes in high cloud cover primarily associated with enhanced convection in the Atlantic ITCZ.

Clearly the reanalysis atmospheric net ocean surface heating trends (Fig. 6) are sensitive to the differences in cloud cover trends (Fig. 8). For the most part, cloud cover trend patterns resemble the $\mathrm{SW}_{\mathrm{ABS}}$ trend patterns, and to a lesser extent the $\mathrm{LW}_{\text {down }}$ trend patterns. Other trends (e.g., $\mathrm{LW}_{\text {up }}, H_{\mathrm{L}}$, and $H_{\mathrm{S}}$ ) adjust, yielding varying balances, depending on the reanalysis. Thus, it is difficult to confidently pinpoint the exact nature of net surface heating trends in the reanalyses due to the sensitivity of the surface radiation balance to clouds. ERAI is judged here to be the most likely outcome, based upon the better agreement of the total cloud fraction with ISCCP and PATMOSX.

The horizontal and vertical heat transport within the ocean mixed layer (i.e., $F_{\mathrm{H}}$ and $F_{\mathrm{V}}$ from Eq. 1) can be estimated from the GODAS and ORA-S3 ocean reanalyses. If we assume the ocean mixed layer is isothermal, then $F_{\mathrm{H}}$ can be estimated from

$F_{\mathrm{H}}=-\rho_{\mathrm{w}} C_{\mathrm{w}} h\left(\overrightarrow{\bar{V}}_{\mathrm{ML}} \cdot \nabla \bar{T}_{\mathrm{ML}}\right)$,

where $\overrightarrow{\bar{V}}_{\mathrm{ML}}$ is the average mixed layer horizontal current and $\bar{T}_{\mathrm{ML}}$ is the average mixed layer temperature. $F_{\mathrm{V}}$ is defined as:

$F_{\mathrm{V}}=-\rho_{\mathrm{w}} C_{\mathrm{w}} h\left(w \frac{\partial T}{\partial z}\right)_{\mathrm{MLB}}$,

where $w$ is the vertical velocity of water, $T$ is the temperature, and $z$ is the vertical depth. This quantity is evaluated at the base of the ocean mixed layer, and represents the transport of heat by the vertical ocean current either into or out of the ocean mixed layer.

Figure $9 \mathrm{a}$ and $\mathrm{b}$ show the November-January climatological $F_{\mathrm{V}}$ for GODAS and ORA-S3. The patterns are
Fig. 9 1982-2013 November-January climatological horizontal heat transport by ocean mixed layer currents $\left(F_{\mathrm{H}} ; \mathrm{W} \mathrm{m}^{-2}\right)$ from a GODAS and b ORA-S3. Also shown is the November-January climatological vertical heat transport at the base of the ocean mixed layer $\left(F_{\mathrm{V}} ; \mathrm{W} \mathrm{m}{ }^{-2}\right)$ from $\mathbf{c}$ GODAS and $\mathbf{d}$ ORA-S3. e and $\mathbf{f}$ Show November-January climatological diffusion $\left(D ; \mathrm{W} \mathrm{m}^{-2}\right)$ estimated as a residual from Eq. 1 for GODAS and ORA-S3, respectively

similar, with positive values over the equatorial Atlantic east of $20^{\circ} \mathrm{W}$ and along the South American coast south of about $15^{\circ} \mathrm{S}$, and negative values elsewhere. Generally, magnitudes of $F_{\mathrm{H}}$ are larger in ORA-S3.

Figure $9 \mathrm{c}$ and $\mathrm{d}$ show November-January climatological values for $F_{\mathrm{V}}$ for GODAS and ORA-S3. The strongest cooling ( $\left.\sim 40-90 \mathrm{~W} \mathrm{~m}^{-2}\right)$ is associated with upwelling over the equatorial Atlantic along the African coast $\left(\sim 10-40 \mathrm{~W} \mathrm{~m}^{-2}\right)$.

Diffusion can be approximated as a residual from Eq. 1. The November-January climatological values for GODAS and ORA-S3 are shown in Fig. 9e, f. Generally, the largest heat loss associated with diffusion appears to occur along the African coast and over the equatorial Atlantic where there is strong upwelling, and hence vertical mixing. There are differences in the magnitudes between the two datasets, but the general climatological pattern is similar. Note some caution is required using a residual approach to estimate diffusion in this manner, as the quantities shown may also include impacts of any numerical errors associated with the determination of the other terms.

Trends in $F_{\mathrm{H}}, F_{\mathrm{V}}$, and diffusion are shown in Fig. 10. There are significant positive trends in $F_{\mathrm{H}}$ (Fig. 10a, b) scattered in the Gulf of Guinea and further south off the Angola/Namibian coast $\left(\sim 10-40 \mathrm{~W} \mathrm{~m}^{-2}\right.$ per 32 years). The latter suggests that the enhanced net surface heating in Fig. 4 near the Angolan Coast is being transported to the south and west by the mixed layer current, moderating the SST warming trend. Over the open ocean, both datasets indicate weak negative trends (i.e., $<-10 \mathrm{~W} \mathrm{~m}^{-2}$ per 32 years) between $18^{\circ} \mathrm{S}$ and $25^{\circ} \mathrm{S}$, and positive trends south of $25^{\circ} \mathrm{S}$.

Agreement between the two datasets for $F_{\mathrm{V}}$ trends is not nearly as strong (Fig. 10c, d). Off the Guinean Coast west of $5^{\circ} \mathrm{W}$ and along the Angolan Coast south of $10^{\circ} \mathrm{S}$, both reanalyses suggest a positive trend in $F_{\mathrm{V}}$ signifying warming associated with a weakening of coastal upwelling, but these trend patterns are spatially complex. Trends from GODAS and ORA-S3 differ considerably over the eastern equatorial Atlantic (i.e., east of $\sim 10^{\circ} \mathrm{W}$ ), with GODAS trends indicating warming while ORA-S3 indicating cooling. While the GODAS trend is more consistent with the SST trend (Figs. 2 and 3), the plausibility of the ORA-S3 $F_{\mathrm{V}}$ trend cannot be dismissed at this time.

Likewise agreement in the diffusion trends varies between the two datasets (Fig. 10e, f). Both reanalyses 

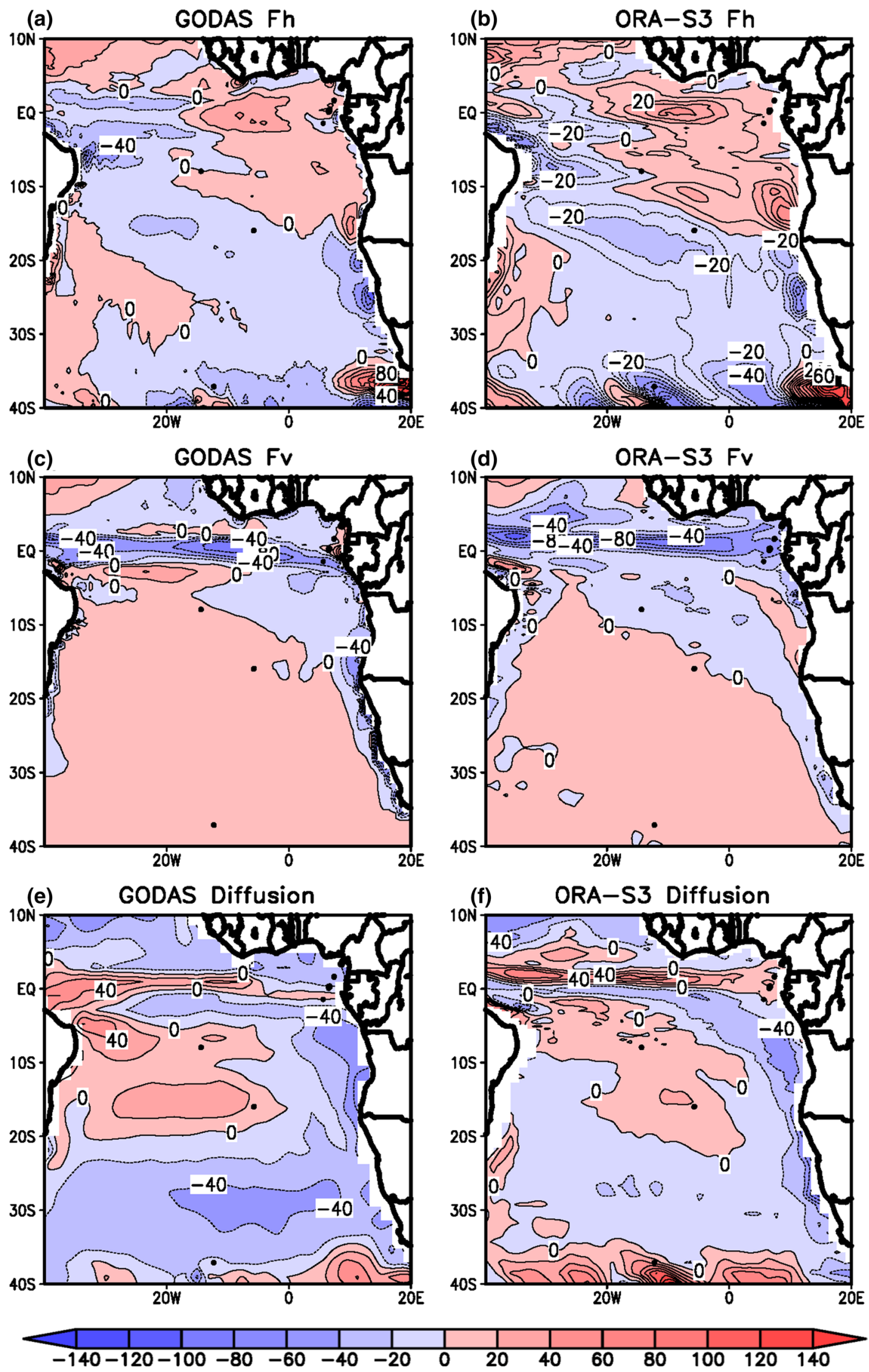
(a) GODAS Fh Trend

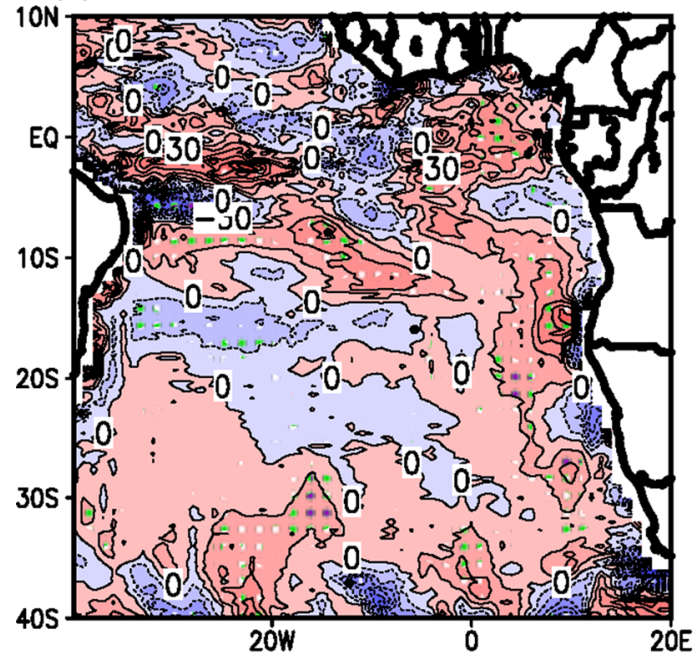

(c) GODAS Fv Trend

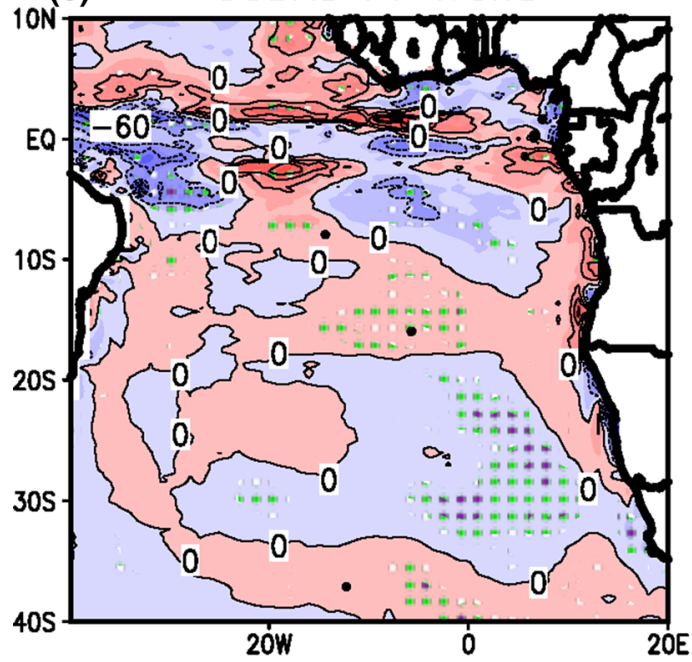

(e) GODAS Diffusion Trend

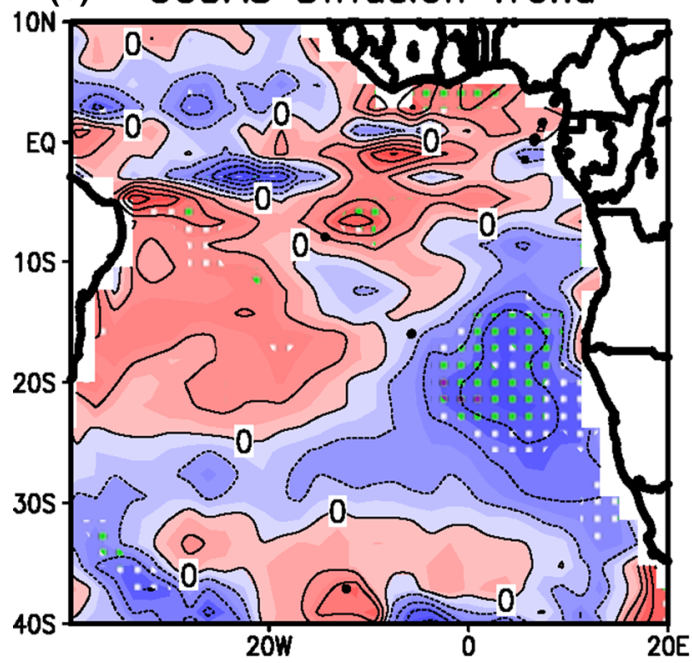

(b) ORA-S3 Fh Trend
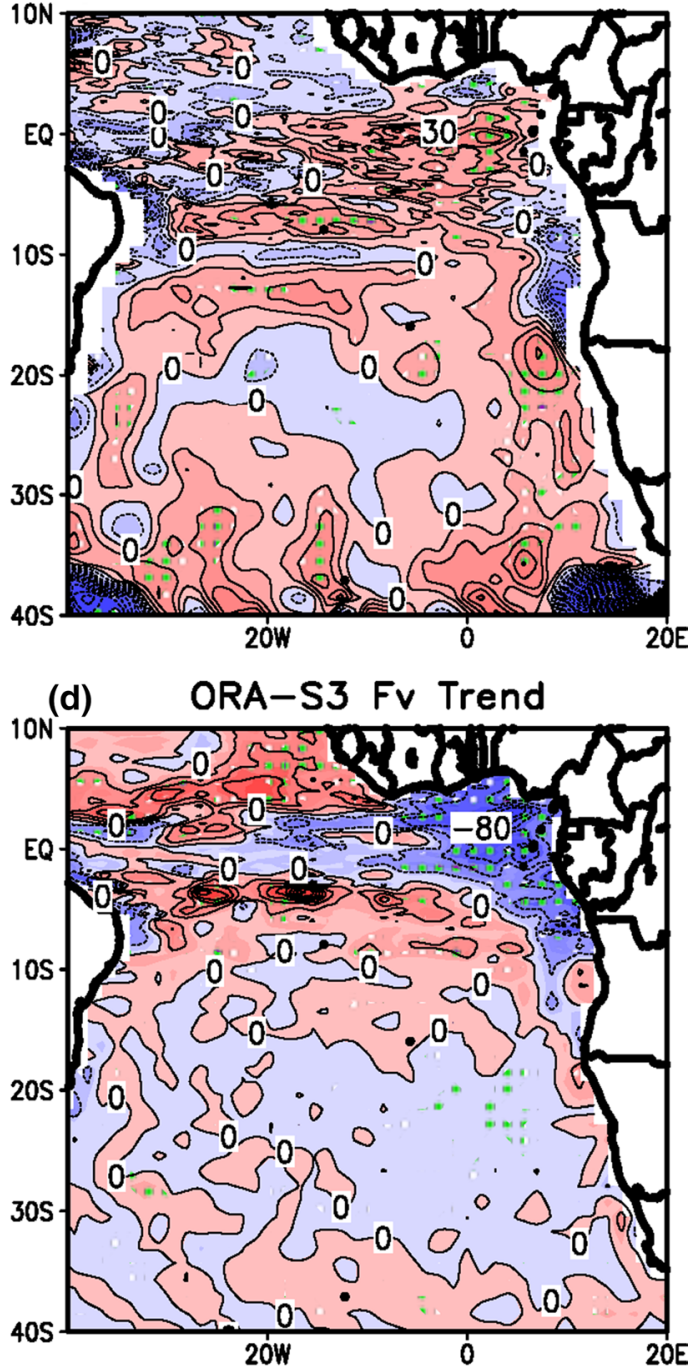

(f) ORA-S3 Diffusion Trend

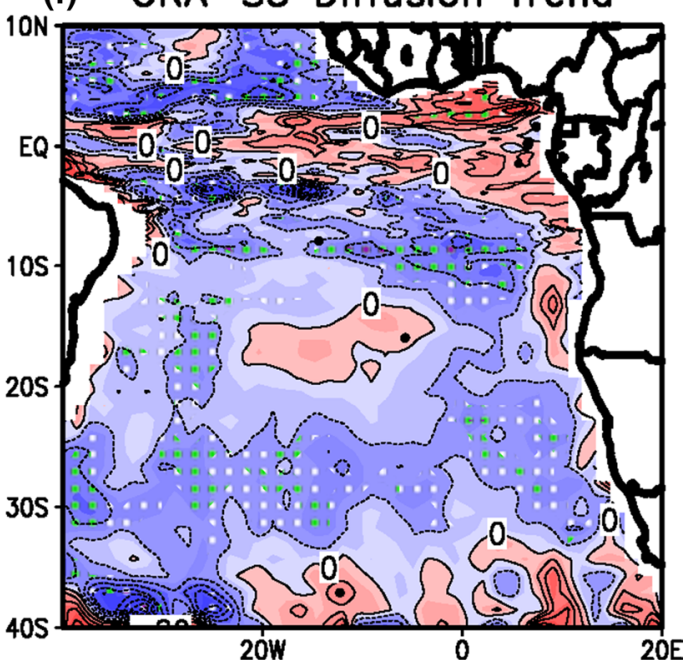

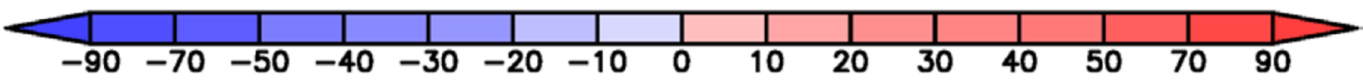


4Fig. 10 1982-2013 November-January linear trends in $F_{\mathrm{H}}$ from a GODAS and b ORA-S3, $F_{\mathrm{V}}$ for $\mathbf{c}$ GODAS and d ORA-S3, and diffusion for e GODAS and $\mathbf{f}$ ORA-S. Units for all are $\mathrm{W} \mathrm{m}^{-2}$ per 32 years. White, green, and purple stippling denotes values found statistically significant at the 90, 95, and $99 \%$ level of confidence, respectively after taking into account autocorrelation

indicate positive trends right along the Angolan and Gulf of Guinea coasts with magnitudes ranging from 5 to $30 \mathrm{~W} \mathrm{~m}^{-2}$ per 32 years. Both reanalyses also indicate the presence of a negative diffusion trend centered along $30^{\circ} \mathrm{S}$. Over the western subtropical South Atlantic between the equator and $25^{\circ} \mathrm{S}$ the diffusion trends are opposite for the two datasets, which is not so surprising given that that climatologies (Fig. 9e, f) differ over this region.

Table 1 summarizes the November-January surface heat balance equation term trend changes in Figs. 4 and 10 for the Angolan coast $\left(10^{\circ} \mathrm{E}-15^{\circ} \mathrm{E} ; 17^{\circ} \mathrm{S}-8^{\circ} \mathrm{S}\right)$, eastern Guinean Coast $\left(0^{\circ} \mathrm{E}-10^{\circ} \mathrm{E} ; 3^{\circ} \mathrm{N}-6^{\circ} \mathrm{N}\right)$, western Guinean Coast $\left(12^{\circ} \mathrm{W}-7^{\circ} \mathrm{W} ; 3^{\circ} \mathrm{N}-6^{\circ} \mathrm{N}\right)$, and central South Atlantic $\left(20^{\circ} \mathrm{W}-10^{\circ} \mathrm{W} ; 25^{\circ} \mathrm{S}-18^{\circ} \mathrm{S}\right)$ regions. Along the Angolan coast GODAS warming trends are found to be associated primarily with positive changes in $F_{\mathrm{V}}$ (4.81 $\mathrm{W} \mathrm{m}^{-2}$ per 32 years) indicating a weakening of the vertical advection of cool water, and a smaller positive trend in the net heat flux $\left(0.75 \mathrm{~W} \mathrm{~m}^{-2}\right.$ per 32 years $)$. The balance is slightly different in ORA-3, with positive net heat flux trends primarily responsible for the warming, while $F_{\mathrm{V}}$ trends are slightly negative $\left(-1.45 \mathrm{~W} \mathrm{~m}^{-2}\right.$ per 32 years) due to the strong negative trends in ORA-3 north of $10^{\circ} \mathrm{S}$ (Fig. 10d) that are not observed in GODAS (Fig. 10c).

The Guinean Coast warming trend west of $8^{\circ} \mathrm{W}$ is found to be associated with a decrease in the vertical advection of cooler water as both GODAS and ORA-S3 suggest positive trends of 9.51 and $20.41 \mathrm{~W} \mathrm{~m}^{-2}$ per 32 years, respectively. Interestingly, the signs of the net heat flux and the diffusion trends differ between GODAS and ORA-S3. The net heat flux for GODAS is from NCEP2 (Fig. 4g), while for ORA$\mathrm{S} 3$ it is from the ERA40 and ECMWF operational analysis, and does not agree with the ERAI trends shown in Fig. 4e. GODAS also suggests that changes in diffusion may also be important, contributing to about half of the warming once differenced from the net heat flux trend. For ORA-S3, diffusion and net heat flux trend changes generally balance, resulting in all of the warming associated with changes in the vertical advection term.

East of $8^{\circ} \mathrm{W}$, GODAS suggests that the coastal warming is associated with an increase in horizontal warm water transport by the generally eastward-flowing mixed layer currents $\left(0.96 \mathrm{~W} \mathrm{~m}^{-2}\right.$ per 32 years) and a positive trend in diffusion (i.e., a decrease in cooling due to diffusion) of $33.60 \mathrm{~W} \mathrm{~m}^{-2}$ per 32 years. In contrast, ORA-S3 indicates that positive trends in net heat flux and diffusion are responsible for the warming trend, but again some caution should be placed in the ORA-3 results since the net heat flux trends disagree with the other reanalyses (Fig. 4e-h).

Over the central South Atlantic region GODAS suggests that the cooling trend is associated primarily with a decrease in the net surface heating $\left(-10.44 \mathrm{~W} \mathrm{~m}^{-2}\right.$ per 32 years) with a smaller contribution from $F_{\mathrm{H}}$ $\left(-1.67 \mathrm{~W} \mathrm{~m}^{-2}\right.$ per 32 years). For ORA-S3 balance is different, as negative $F_{\mathrm{H}}, F_{\mathrm{V}}$, and diffusion trends offset the increases in net surface heating and determine the change in cooling.

The heat transport in the ocean mixed layer is strongly influenced by the overlying atmospheric circulation and surface wind stress. Figure 11a-g show the austral summer sea-level pressure climatology over the Atlantic and Indian

Table 1 November-January regional area-averages of surface heat balance equation term trends ( $\mathrm{W} \mathrm{m}^{-2}$ per 32 years)

\begin{tabular}{|c|c|c|c|c|}
\hline Term & $\begin{array}{l}\text { GODAS Angolan coast } \\
(10 \mathrm{E}-15 \mathrm{E} ; 17 \mathrm{~S}-8 \mathrm{~S})\end{array}$ & $\begin{array}{l}\text { GODAS Eastern Guinean } \\
\text { Coast }(0-10 \mathrm{E} ; 3 \mathrm{~N}-6 \mathrm{~N})\end{array}$ & $\begin{array}{l}\text { GODAS Western Guinean } \\
\text { Coast }(12 \mathrm{~W}-7 \mathrm{~W} ; 3 \mathrm{~N}-6 \mathrm{~N})\end{array}$ & $\begin{array}{l}\text { GODAS Central South Atlantic } \\
(20 \mathrm{~W}-10 \mathrm{~W} ; 25 \mathrm{~S}-18 \mathrm{~S})\end{array}$ \\
\hline $\mathrm{C} \partial \mathrm{T}_{\mathrm{s}} / \partial \mathrm{t}$ & 2.29 & 1.27 & 4.62 & -4.69 \\
\hline Net heat flux & 0.75 & -29.06 & -26.88 & -10.44 \\
\hline$F_{\mathrm{H}}$ & -1.14 & 0.96 & -7.01 & -1.67 \\
\hline$F_{\mathrm{V}}$ & 4.81 & -4.23 & 9.51 & 0.57 \\
\hline Diffusion & -2.13 & 33.60 & 29.00 & 6.85 \\
\hline Term & $\begin{array}{l}\text { ORA-S3 Angolan coast } \\
(10 \mathrm{E}-15 \mathrm{E} ; 17 \mathrm{~S}-8 \mathrm{~S})\end{array}$ & $\begin{array}{l}\text { ORA-S3 Eastern Guinean } \\
\text { Coast }(0-10 \mathrm{E} ; 3 \mathrm{~N}-6 \mathrm{~N})\end{array}$ & $\begin{array}{l}\text { ORA-S3 Western Guinean } \\
\text { Coast }(12 \mathrm{~W}-7 \mathrm{~W} ; 3 \mathrm{~N}-6 \mathrm{~N})\end{array}$ & $\begin{array}{l}\text { ORA-S3 Central South Atlantic } \\
(20 \mathrm{~W}-10 \mathrm{~W} ; 25 \mathrm{~S}-18 \mathrm{~S})\end{array}$ \\
\hline $\mathrm{C} \partial \mathrm{T}_{\mathrm{s}} / \partial \mathrm{t}$ & 2.78 & 7.34 & 15.78 & -7.60 \\
\hline Net heat flux & 33.94 & 29.49 & 35.62 & 11.19 \\
\hline$F_{\mathrm{H}}$ & -20.83 & -5.51 & -4.76 & -4.55 \\
\hline$F_{\mathrm{V}}$ & -1.45 & -60.89 & 20.41 & -1.64 \\
\hline Diffusion & -8.88 & 44.25 & -35.49 & -12.60 \\
\hline
\end{tabular}



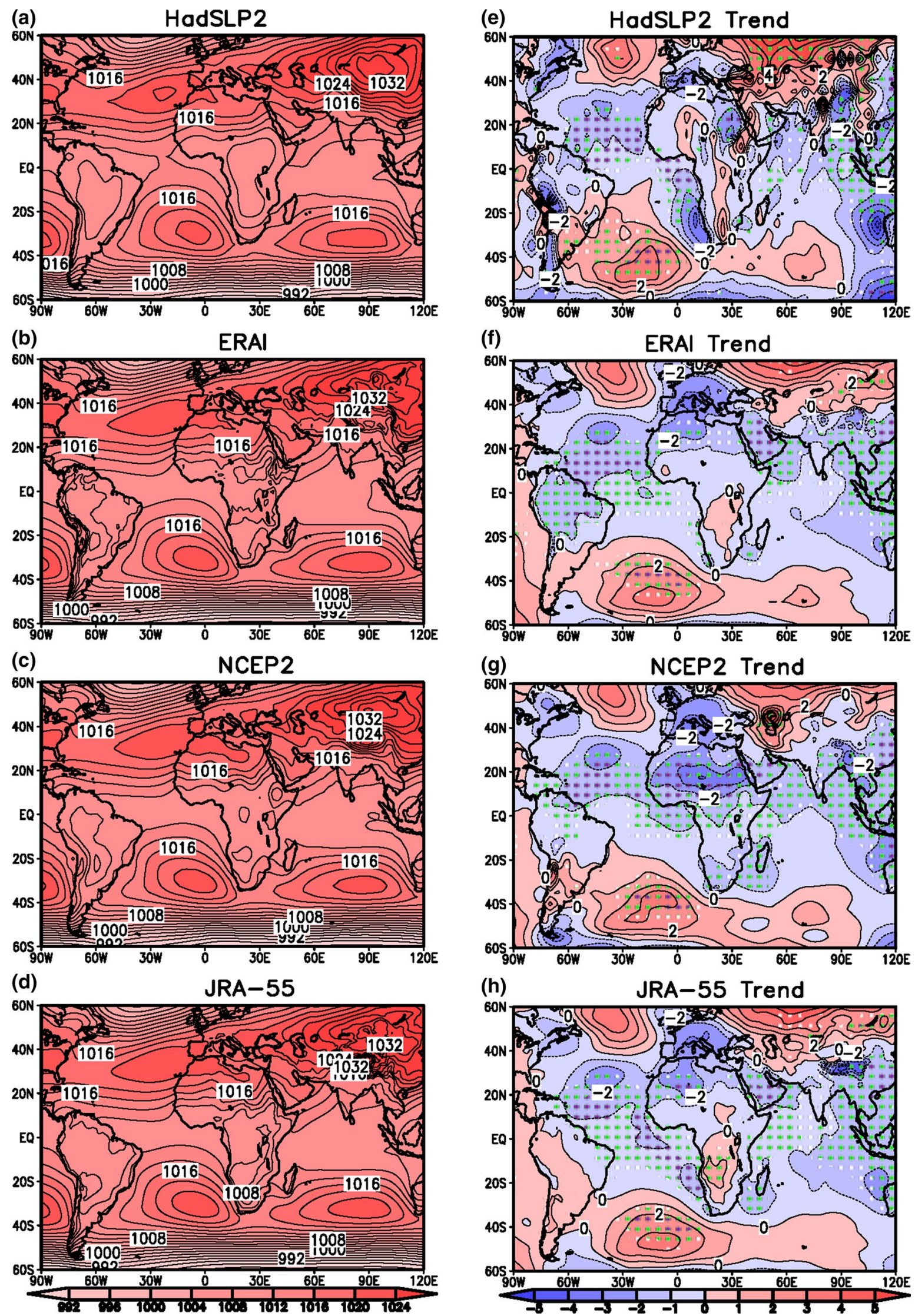
4Fig. 11 1982-2013 November-January climatological mean sealevel pressure (left column; hPa) and linear trends of mean sea-level pressure (right column; hPa per 32 years) for the HadSLP2 dataset and the ERAI, NCEP2, and JRA-55 reanalyses. White, green, and purple stippling denotes values found statistically significant at the 90,95 , and $99 \%$ level of confidence, respectively after taking into account autocorrelation

Oceans for the HadSLP2 (Fig. 11a) and the three reanalyses (Fig. 11b-d). The dominant features include anticyclones over the South Atlantic and South Indian Oceans at $35^{\circ} \mathrm{S}$, the Tibetan Plateau at $40^{\circ} \mathrm{N}$, and eastern North Atlantic/western Mediterranean Sea around $30^{\circ} \mathrm{N}$. Over land, relatively low sea-level pressures are observed over South America at $20^{\circ} \mathrm{S}$ (the Chaco low) and over southwestern Southern Africa near $20^{\circ} \mathrm{S}$ (the Angolan thermal low).

Figure 11e-h show the November-January sea-level pressure trends for each dataset. Magnitudes vary, but there is good agreement among the datasets regarding a poleward shift in the subtropical anticyclones in both hemispheres consistent with the observed long-term trend of positive polarity of the Southern Annular mode, which is associated with a poleward contraction of the mid-latitude westerly wind belt towards Antarctica (Thompson and Wallace 2000; Thompson et al. 2000; Manatsa et al. 2013), and the observed poleward expansion of the Hadley circulation and widening of the tropical belt ( $\mathrm{Hu}$ and $\mathrm{Fu} 2007$; Seidel and Randel 2008; Seidel et al. 2008; Hu et al. 2013). Positive sea-level pressure trends for the South Atlantic and Siberian anticyclones are significant at the $95 \%$ confidence level for all of the datasets. Significant negative sea-level pressure trends occur over the equatorial and tropical North Atlantic and the tropical Indian Ocean, indicative of lower sea-level pressure during the austral summer months. Over southern Africa, there are significant negative trends in the southwest, while all the datasets except NCEP2 show positive trends over the continental interior extending northward into equatorial Africa. This trend pattern indicates an intensification of the austral summer thermal low over the western Kalahari Desert which is further confirmed in Fig. 12 below.

Associated with these changes in sea-level pressure are changes in the low-level circulation. Figure 12a-c show November-January climatological $10-\mathrm{m}$ winds from the three atmospheric reanalyses. Over the South Atlantic the circulation is anticyclonic, with strong southerly/southeasterly flow off the Namibian coast that becomes more easterly over the central South Atlantic between $10^{\circ} \mathrm{S}$ and $20^{\circ} \mathrm{S}$, and eventually northeasterly along the South American coast. Flow over the African continent is weaker, with onshore westerly/southwesterly flow from the South Atlantic converging over land with easterly flow from the Indian Ocean.
Figure $12 \mathrm{~d}-\mathrm{f}$ show the austral summer $10-\mathrm{m}$ wind trends from the reanalyses. South of $20^{\circ} \mathrm{S}$ over the South Atlantic there is an enhancement of the anticyclonic flow in all reanalyses, associated with the poleward shift of the South Atlantic anticyclone (Fig. 11). North of $20^{\circ} \mathrm{S}$, the equatorward component of the flow is stronger in all three datasets, consistent with a weakening of the ridging over the central tropical South Atlantic during the austral summer. Over the Congo basin, ERAI (Fig. 12d) and JRA-55 (Fig. 12f) indicate anomalous anticyclonic circulation with a weakening of the onshore flow over northern Angola, Congo, Democratic Republic of Congo, and Gabon, and a general strengthening of the westerly flow further south over southern Angola and Namibia associated with an intensification of the thermal low over southwestern Africa. NCEP2 (Fig. 12e) also indicates an intensification in the westerly flow over southern Angola/Namibia, while the onshore flow over equatorial Africa strengthens.

Precipitation trends are examined to help evaluate which circulation trend pattern in Fig. 13 is more plausible, since there are a variety of independent monthly rainfall datasets available that cover the $1982-2013$ period. Note precipitation is not assimilated in the atmospheric reanalyses, so rainfall is determined by the assimilation model of each reanalysis. Figure 13a-f show the November-January rainfall climatology from three observational datasets and the three reanalyses, while Fig. 13g-1 show the precipitation trends for the same datasets. All of the datasets are in agreement regarding positive rainfall trends over the equatorial North Atlantic and southern Africa south of approximately $18^{\circ} \mathrm{S}$. Over the Congo basin, GPCP (Fig. 13g), CRU (Fig. 13e), and ARC2 (Fig. 13f) indicate a negative trend in rainfall, consistent with rainfall trends calculated from ERAI (Fig. 13j) and JRA-55 (Fig. 131). However, NCEP2 (Fig. 13k) indicates a positive rainfall trend over most of the Congo basin.

Precipitation is connected to the circulation through the vertically-integrated moisture flux convergence. Figure $14 \mathrm{a}-\mathrm{c}$ show the austral summer vertically-integrated moisture flux convergence from the ERAI, NCEP, and JRA-55 reanalyses, respectively, while Fig. $14 \mathrm{~d}-\mathrm{f}$ show the vertically integrated moisture flux convergence trends. Over the Congo basin, ERAI and JRA-55 show a significant negative trend, indicating a weakening of the vertically-integrated moisture flux convergence over this region, while NCEP2 has the opposite trend. Further decomposition of the atmospheric moisture budget and analysis of the precipitable water trends (not shown) indicates that the negative vertically-integrated moisture flux convergence trend over the Congo basin is associated with primarily changes in the wind convergence and not changes in the atmospheric column moisture content, while over subtropical Southern Africa, south of $10^{\circ} \mathrm{S}$, both changes in circulation 

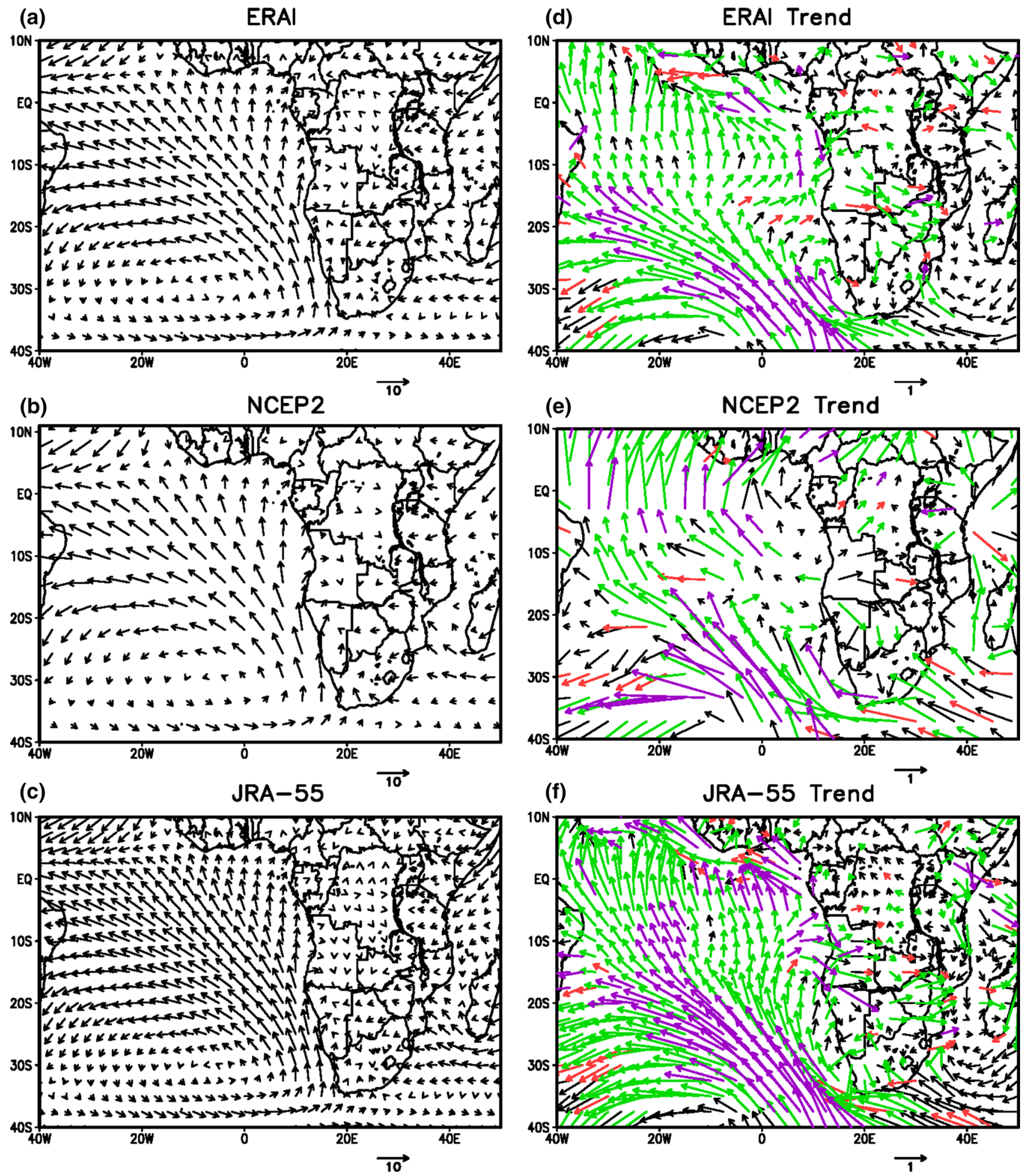

Fig. 12 1982-2013 November-January climatological mean 10-m wind (left column $\mathbf{a}-\mathbf{c} ; \mathrm{m} \mathrm{s}^{-1}$ ) and linear trends of $10-\mathrm{m}$ wind (right column $\mathbf{d}-\mathbf{f} ; \mathrm{m} \mathrm{s}^{-1}$ per 32 years) for the ERAI, NCEP2, and JRA-55

reanalyses. Red, green, and purple vectors in $\mathbf{d}, \mathbf{e}$, and $\mathbf{f}$ denote values that are statistically significant at the 90,95 , and $99 \%$ level of confidence, respectively after taking into account autocorrelation

and atmospheric column moisture content are important. Thus, while NCEP2 precipitation trends over the Congo basin appear to be internally consistent with the circulation

trends, they are not consistent with independently-observed rainfall trends, suggesting that the ERAI and JRA-55 circulation trends in Fig. 12 are more realistic. For this reason 
Fig. 13 1982-2013 November-January climatological precipitation (left column; $\mathrm{mm} \mathrm{day}^{-1}$ ) and linear trends of precipitation (right column; mm day ${ }^{-1}$ per 32 years) for the GPCP, CRU, and ARC2 observations and the ERAI, NCEP2, and JRA-55 reanalyses. White, green, and purple stippling denotes values found statistically significant at the 90,95 , and $99 \%$ level of confidence, respectively after taking into account autocorrelation
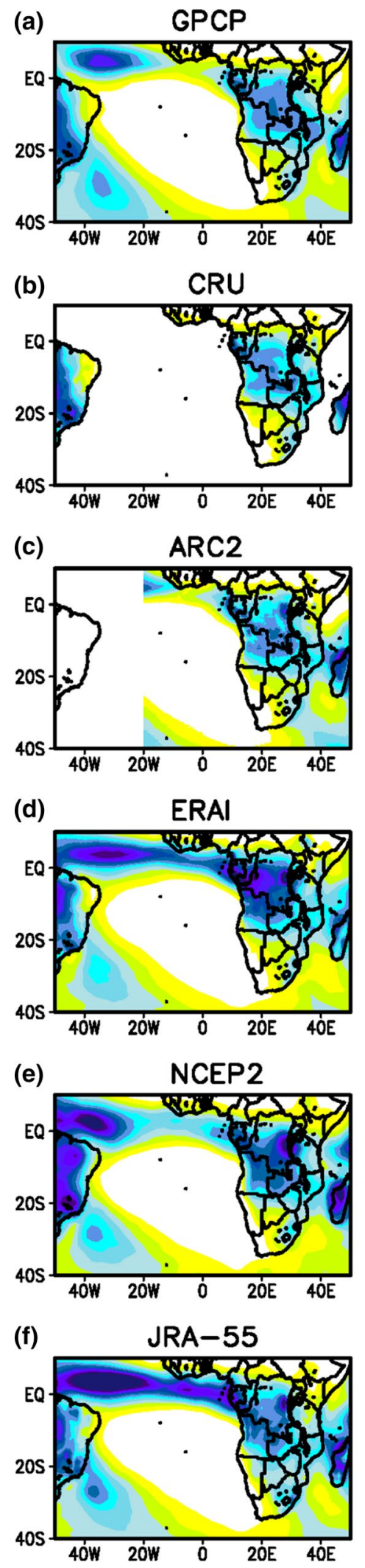

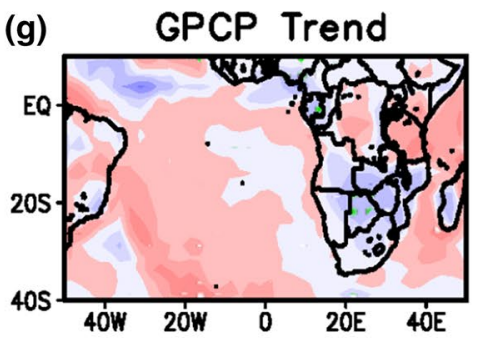

(h)

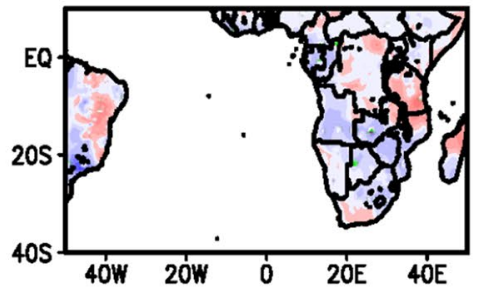

(i)
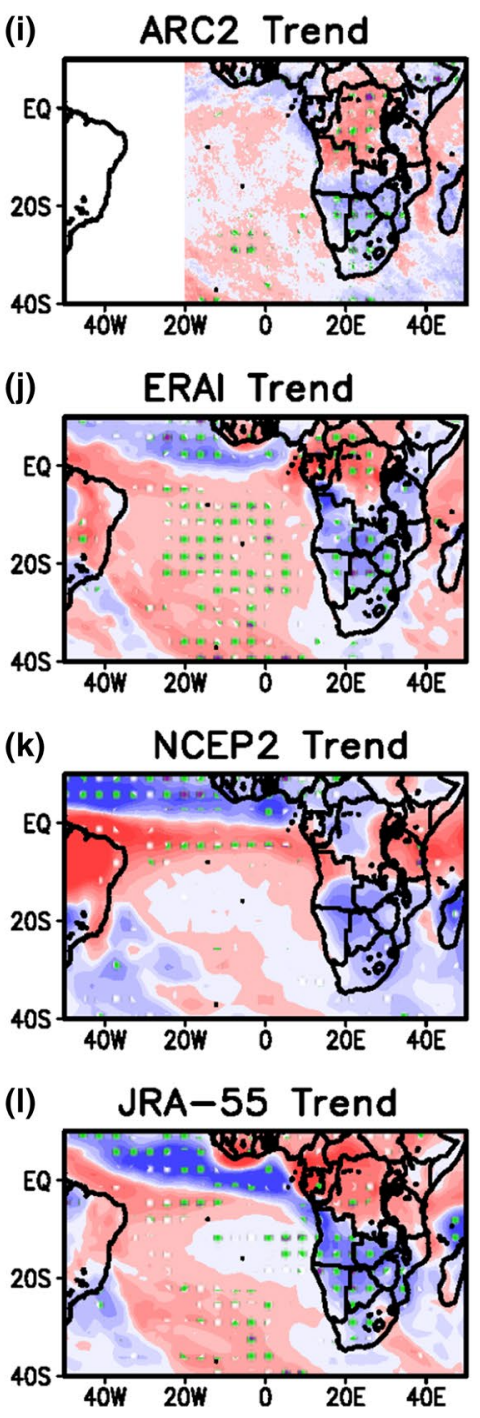
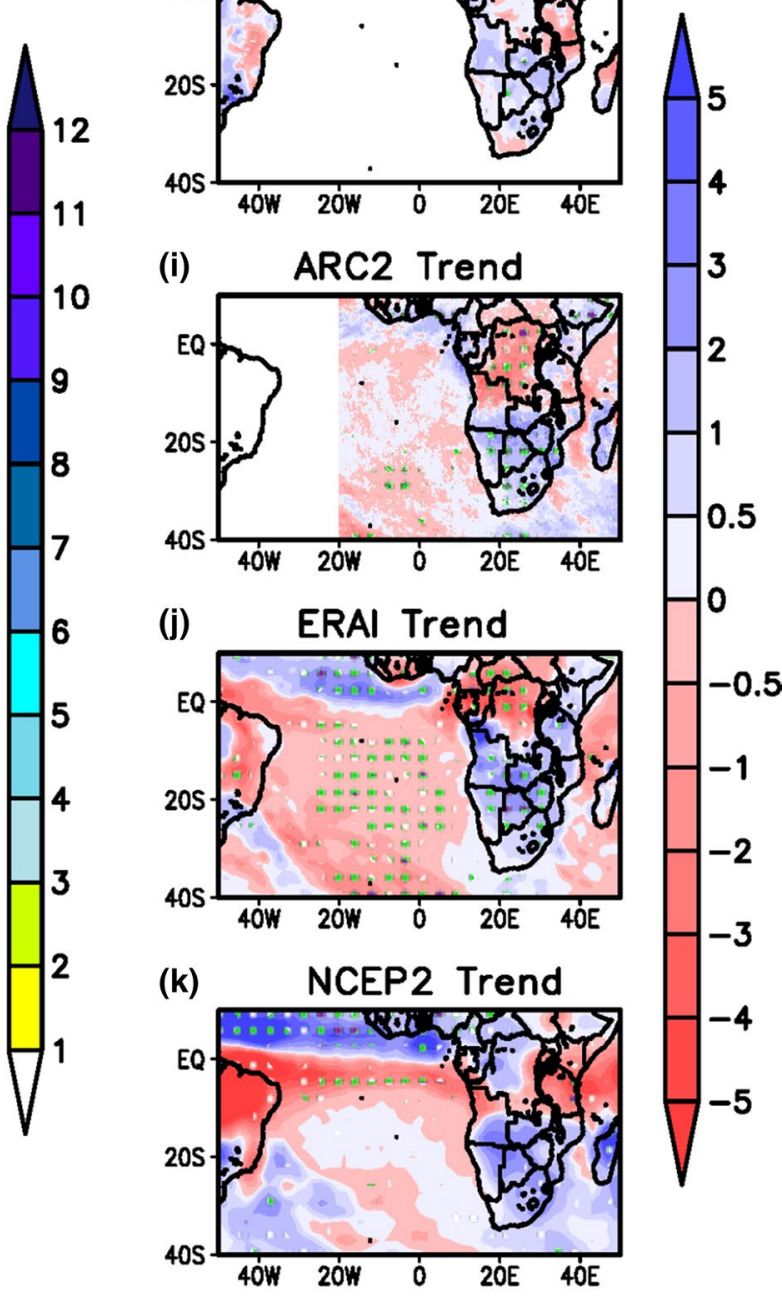

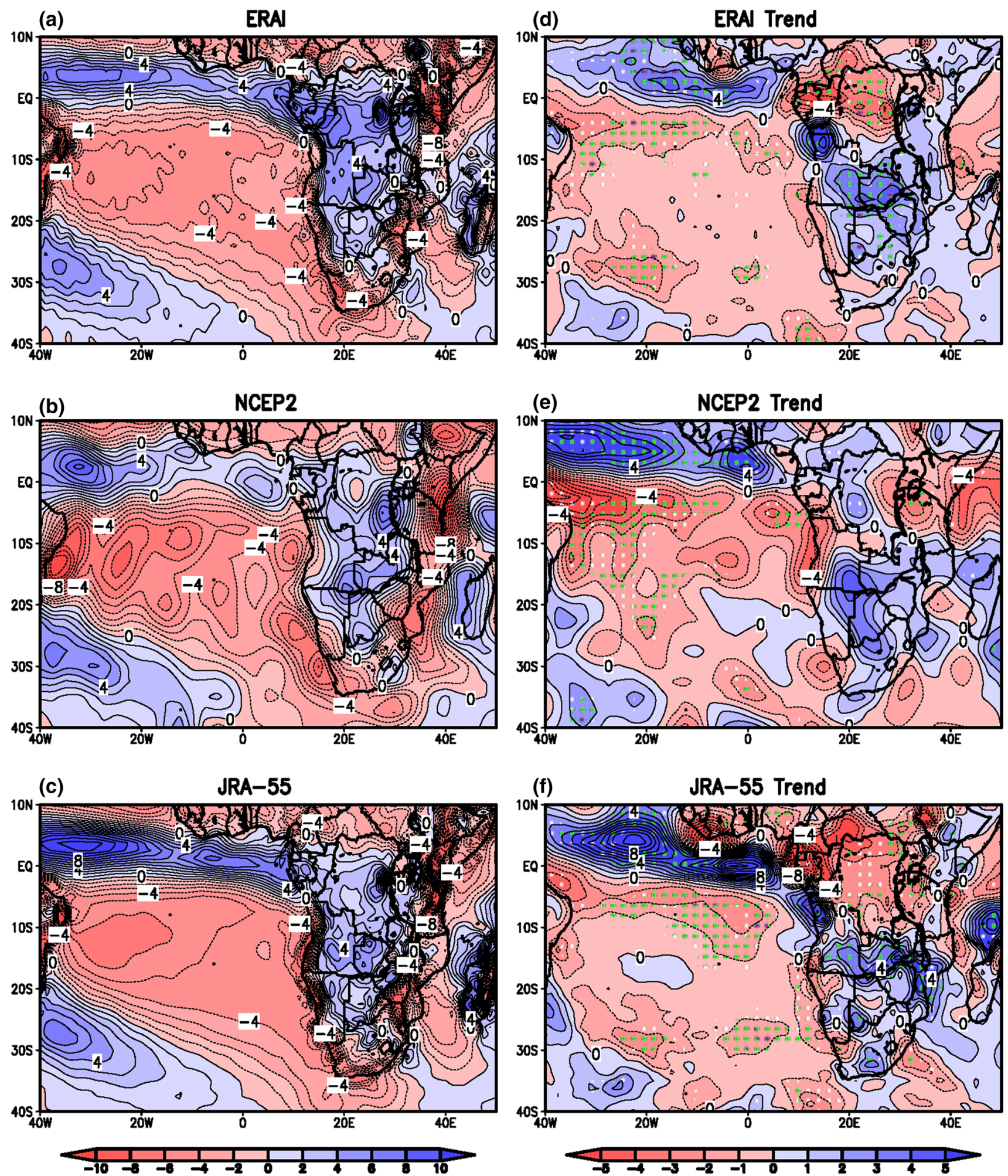

Fig. 14 1982-2013 November-January climatological mean vertically-integrated moisture flux convergence (left column a-c; $\mathrm{mm} \mathrm{day}{ }^{-1}$ ) and linear trends of vertically- integrated moisture flux convergence (right column $\mathbf{d}-\mathbf{f}$; $\mathrm{mm} \mathrm{day}^{-1}$ per 32 years) for the

ERAI, NCEP2, and JRA-55 reanalyses. White, green, and purple stippling in $\mathbf{b}, \mathbf{e}$, and $\mathbf{f}$ denotes values found statistically significant at the 90,95 , and $99 \%$ level of confidence, respectively after taking into account autocorrelation 

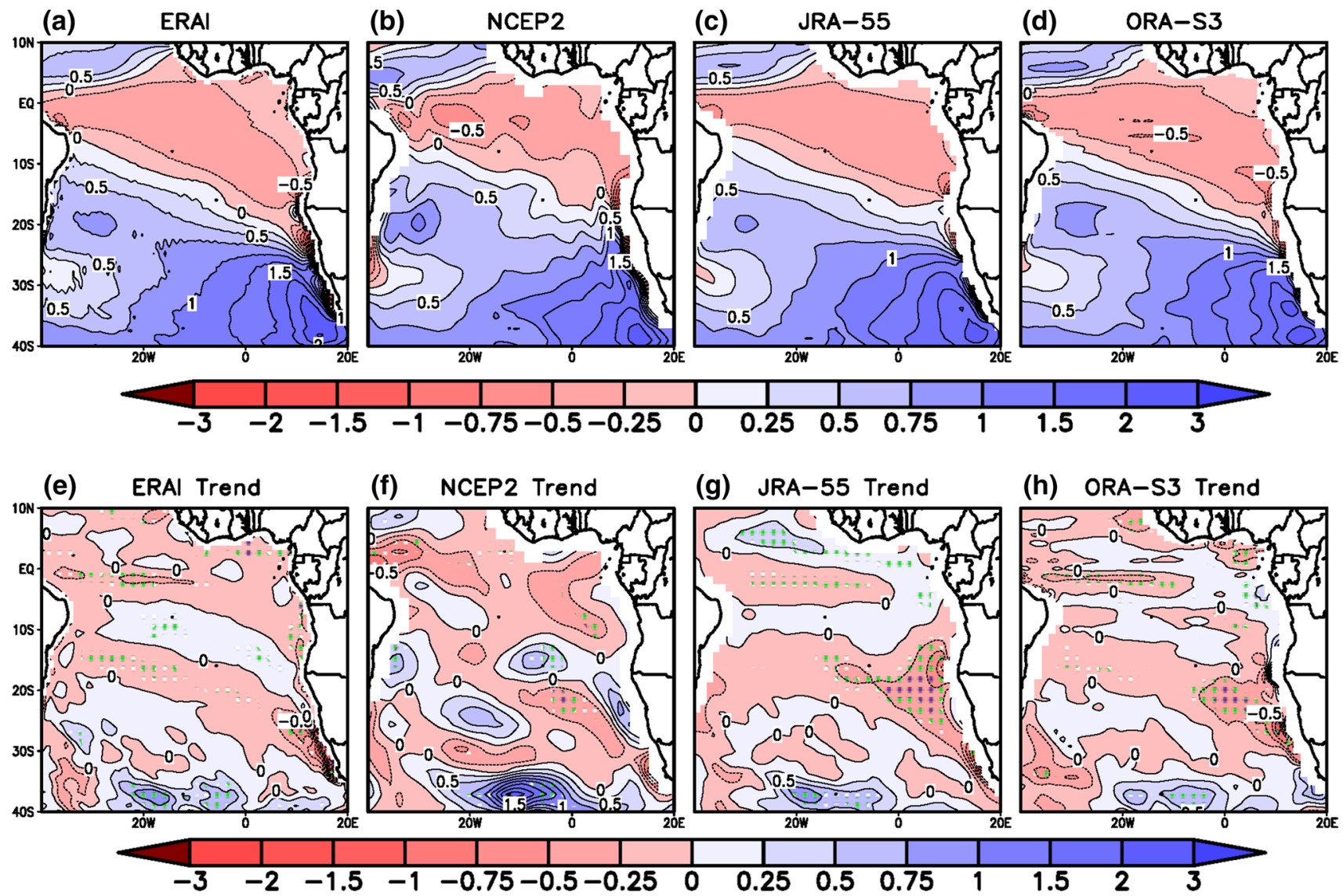

(h) ORA-S3 Trend

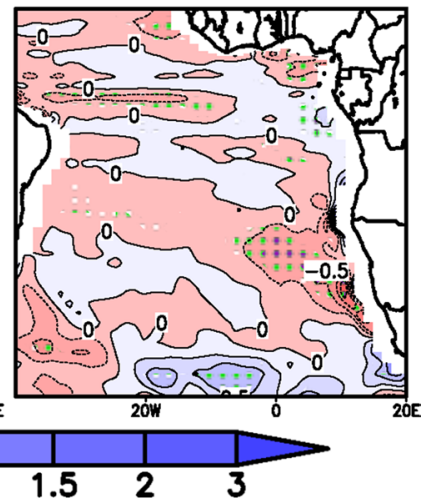

Fig. 15 (Top row) Climatological November-January seasonal curl of the ocean wind stress $\left(\times 10^{7} \mathrm{~N} \mathrm{~m}^{-3}\right)$ for a ERAI, b NCEP2, c JRA55, and d ORA-S3. (Bottom row) November-January trends in the curl of the ocean wind stress $\left(\times 10^{7} \mathrm{~N} \mathrm{~m}^{-3}\right.$ per 32 years $)$ for e ERAI, f NCEP2, g JRA-55, and h ORA-S3. White, green, and purple stippling denotes values found statistically significant at the 90,95 , and $99 \%$ level of confidence, respectively after taking into account autocorrelation and based upon ERAI having better agreement with the observed SST trends in Fig. 2 relative to JRA-55, the ERAI trends are likely more reliable.

The sea-level pressure, near surface winds, and precipitation trend patterns discussed above are consistent with Vigaud et al.'s (2009) negative phase South Atlantic mid-latitude mode of interannual variability derived from January to February 1979-2000 NCEP2 reanalysis and CRUTS2.0 precipitation observations. The trend analysis presented here indicates that this particular pattern of variability is intensifying and/or becoming more prevalent. However, unlike Vigaud et al. (2009), our analysis also indicates a significant response over equatorial Africa.

Finally, the curl of the ocean wind stress is examined to connect the near surface wind trends back to the SST trends (Fig. 2). Figure 15 shows the curl of the ocean wind stress for ERAI (Fig. 15a), NCEP2 (Fig. 15b), JRA-55 (Fig. 15c), and ORA-S3 (Fig. 15d) in the austral summer climatology. GODAS is not shown because it uses surface wind stress forcing from NCEP2, and hence yields the same outcome as NCEP2. The climatologies all indicate negative curl (cyclonic rotation) over the eastern tropical and sub-tropical South Atlantic Ocean north of about $18^{\circ} \mathrm{S}$. South of $20^{\circ} \mathrm{S}$ there is positive curl (anticyclonic rotation) associated with circulation around the South Atlantic anticyclone. Magnitudes are largest just off the Namibian/South African coast, coinciding with the strongest surface wind speeds (Fig. 12).

Figure 15e-h show the austral summer curl trends from the reanalyses. Agreement varies by region, but all datasets show a negative trend over the South Atlantic between $18^{\circ} \mathrm{S}$ and $25^{\circ} \mathrm{S}$ and a positive trend near $35^{\circ} \mathrm{S}$. There is weakening of the anticyclonic rotation in the subtropical South Atlantic and a strengthening of the anticyclonic rotation at mid-latitudes, consistent with a poleward shift in the South Atlantic anticyclone (Fig. 11) and, consistent with the observed changes in $F_{\mathrm{H}}$ (Fig. 10) across the basin. The datasets also show a significant negative trend just south of the equator over the central Atlantic between $0^{\circ} \mathrm{W}$ and $30^{\circ} \mathrm{W}$, indicating an increase in cyclonic curl associated with weaker ridging over the central tropical South Atlantic (Fig. 11). Off the Angolan coast there is a discernible 
negative trend, but the spatial pattern varies among the reanalyses. For example, the negative trend is positioned along the coast in ERAI and JRA-55, but it is further west in NCEP2 and ORA-S3. Given that the NCEP2 near surface wind trends (Fig. 12) are inconsistent with the observed rainfall trends (Figs. 13, 14) as discussed above, the trends in the curl of the near surface wind in ERAI and JRA-55 are likely to be more reliable. Thus, SST warming off the Angola coast is also associated with the combined effects of the poleward shift of the South Atlantic anticyclone and an intensification of the austral summer thermal low over southwestern Africa. The distinct seasonality of the significant SST trend response may be related to the influence of the land-based atmospheric circulation. While the Angolan thermal low is dominant during the austral summer, the circulation over continental southern Africa is dominated by the Kalahari anticyclone during the austral winter. This coincides with a weaker SST warming trend off the Angola coast (Fig. 3a), despite that fact that there is still a poleward shift of the South Atlantic anticyclone during the austral winter (not shown).

\section{Conclusions}

High-resolution observational datasets, atmospheric reanalyses, and ocean reanalyses are examined to understand how and why southeastern Atlantic SSTs have changed over the 1982-2013 period. Multiple datasets are examined to evaluate confidence in the trends identified, and to help identify artificial discontinuities associated with operational changes over the analysis period.

Significant warming trends in annual SSTs off the Guinean and Angolan/Namibian Coasts ranging from 0.5 to $1.5 \mathrm{~K}$ per 32-years, and over the open South Atlantic Ocean south of $30^{\circ} \mathrm{S}$ ranging from 0.25 to $0.75 \mathrm{~K}$ per 32 -years, are identified in the majority of the datasets analyzed (Fig. 2). A cooling trend of -0.10 to $-0.60 \mathrm{~K}$ per 32 years is observed over the subtropical South Atlantic (i.e., between $18^{\circ} \mathrm{S}$ and $28^{\circ} \mathrm{S}$ ), but this trend is robustly significant at the $99 \%$ confidence level for only two of the eight datasets analyzed. SST trends vary over the annual cycle, with the most significant SST trends occurring during the austral summer months of November-January (Fig. 3).

Examination of the ocean surface heat budget (Eq. 1) suggests that the austral summer SST warming trend over the southeastern South Atlantic Ocean off the Angola coast is associated with an increase in the net heat flux from the atmosphere (Fig. 4). Three of the four atmospheric reanalyses evaluated are in agreement and the outlier, MERRA, is shown to have artificial data discontinuities in the late 1990s. Exactly how this positive trend in net heat flux is established varies among the remaining three atmospheric reanalyses (Fig. 6), so results are less conclusive. For example, positive trends in $\mathrm{SW}_{\mathrm{ABS}}$ are primarily responsible for the increase in net heat flux from the atmosphere for ERAI and NCEP2, while positive trends in $H_{\mathrm{L}}$ and $\mathrm{LW}_{\text {down }}$ are important in JRA-55. Differences among the reanalyses are shown to be associated with cloud cover trend differences (Fig. 8).

The Angola coast warming trend is also associated with a decrease in coastal upwelling (Fig. 10). Both ocean reanalyses analyzed indicate positive trends (reduced upwelling contributing to warming) off the Angolan coast with the trend more robust in GODAS. Investigation of the austral summer atmospheric circulation trends in the atmospheric reanalyses support the notion of weaker upwelling. Mean sea-level pressure and wind field trends indicate a poleward shift of the South Atlantic subtropical anticyclone and an intensification of the continental thermal low over southwestern Africa over southern Angola, Namibia, and South Africa (Figs. 11, 12). These atmospheric circulation changes combine to enhance the negative curl of the ocean wind stress (i.e., increase the cyclonic rotation) in the southeast Atlantic between the equator and $20^{\circ} \mathrm{S}$ (Fig. 15) and weaken coastal upwelling off the Angola Coast.

The SST cooling trend over the subtropical South Atlantic between $20^{\circ} \mathrm{S}$ and $30^{\circ} \mathrm{S}$ is associated with a negative trend in the net heat flux from the atmosphere. This decrease is primarily associated with a decrease in $H_{\mathrm{L}}$ (i.e., increased latent flux from the ocean), with negative trends in $\mathrm{LW}_{\text {down }}, \mathrm{SW}_{\mathrm{ABS}}$, and $H_{\mathrm{S}}$ also contributing. These changes are in turn associated with the poleward shift of the South Atlantic anticyclone and the intensification of surface wind speeds over this region (Fig. 12). Changes in the horizontal $\left(F_{\mathrm{H}}\right)$ and vertical $\left(F_{\mathrm{V}}\right)$ transport of heat within the ocean mixed layer (Fig. 10) also appear to be contributing to the cooling trend over the subtropical South Atlantic, though the magnitude of these changes are two to four times smaller than the change in $H_{\mathrm{L}}$. This trend is consistent with the response associated with the positive South Atlantic Dipole mode phase of interannual variability (Venegas et al. 1997; Haarsma et al. 2005; Morioka et al. 2011; Yuan et al. 2014) suggesting that this pattern has likely been intensifying and/or become more prominent over the past 32 years.

Positive austral summer SST trends along the Guinean coast north of the equator are not directly associated with net atmospheric surface heat flux trends over the region; the trends are negative for the atmospheric reanalyses analyzed (i.e., less heat into the ocean surface from the atmosphere). This suggests that the observed positive SST trend is associated with changes internal to the ocean. Evaluation of two ocean reanalyses suggests that the warming trend west of $8^{\circ} \mathrm{W}$ is associated with a decrease in coastal upwelling and possibly diffusion, while the warming trend east of 
$8^{\circ} \mathrm{W}$ is associated with a positive trend in diffusion and an increase in the horizontal warm water transport by the ocean mixed layer, primarily from the west. Note, a caveat of our evaluation of the surface heat budget for the ocean (Eq. 1 ) is that the diffusion term, $D$, cannot be directly calculated for the ocean reanalyses, and is estimated here as a residual instead. This means that the quantities shown here for $D$ may also include numerical errors associated with the determination of the other terms, and should be treated with caution in their interpretation.

The austral summer circulation trends described above, namely, the poleward shift in the South Atlantic subtropical anticyclone and the intensification of the continental thermal low over southwestern Africa, are likely associated with changes in anthropogenic forcing. For example, the poleward shift of the South Atlantic anticyclone is consistent with the observed poleward expansion of the Tropics (Quan et al. 2004, 2014; Lu et al. 2007; Seidel et al. 2008; Johanson and Fu 2009; Nguyen et al. 2013; Choi et al. 2014). Factors such as the depletion in stratospheric ozone (Polvani et al. 2011; McLandress et al. 2011) and the increase in black carbon aerosols and tropospheric ozone (Allen et al. 2012) are thought to play primary roles in the widening of the tropics, although whether the radiative effects are directly forced (Lu et al. 2009) or mediated through SST warming (Staten et al. 2011; Quan et al. 2014) has not been established. The loss of stratospheric ozone is thought to be associated with a delayed breakdown of the stratospheric polar vortex (Trenberth and Olson 1989; Hurrell and van Loon 1994; Randel and Wu 1999) and affects the large-scale southern hemisphere circulation by favoring a positive phase of the Southern Annular mode (Thompson and Solomon 2002; Manatsa et al. 2013). The intensification of the continental thermal low over southwestern Africa is associated with an amplified warming effect over the Kalahari Desert similar to the one observed over the Sahara (Cook and Vizy 2015).

These results are relevant for improving our understanding of regional climate variability associated with global warming over the South Atlantic. While CMIP5 model projections predict continued expansion of the tropics during the twenty-first century (Hu et al. 2013), how this response to global warming manifests over the South Atlantic will depend, in large part, on how much continental Africa warms relative to the adjacent oceans. More work is needed to better understand the sensitivity of the interaction between the South Atlantic subtropical anticyclone and the continental thermal low.

Finally, a better understanding of why the SST trends are most significant in the austral summer months is also needed. Results from this study suggest that the annual cycle of surface heating over continental Africa is playing an important role. Surface temperatures are warmest over the Kalahari Desert during the austral summer, driving the formation and maintenance of the thermal low over southwestern Africa that is shown here to influence the regional climate over the eastern South Atlantic. Another plausible hypothesis that warrants attention relates to the role of stratospheric ozone forcing. Stratospheric ozone concentrations are typically lowest during the austral spring over Antarctica, while an analogous high latitude Northern Hemisphere reduction in ozone concentrations during the boreal spring does not typically reach the same magnitudes or spatial scales. Studies have suggested that ozone depletion is an important driver of the poleward expansion of the Southern Hemisphere tropics during the austral summer months. It has likely influenced Southern Hemisphere circulation trends (Polvani and Kushner 2002; Polvani et al. 2011; McLandress et al. 2011) through its relationship with the Southern Annular mode (Thompson et al. 2000; Manatsa et al. 2013), which is observed to be most active during the late austral spring (Thompson and Wallace 2000; Thompson et al. 2000). Further work is needed to better understand the exact roles of each of these mechanisms and how they interact.

Acknowledgments This research was supported by award NNX13AQ76G from NASA’s Physical Oceanography Program. Any opinions, findings, and conclusions or recommendations expressed in this material are those of the authors and do not necessarily reflect the views of NASA. The Texas Advanced Computing Center (TACC) at the University of Texas at Austin provided the high performance computing and database resources. We also gratefully acknowledge the Global Modeling and Assimilation Office (GMAO) and the GES DISC for the dissemination of MERRA, the Climate Prediction Division of the Japan Meteorological Agency for the dissemination of JRA-55, and the Climate Prediction Center of NOAA for the dissemination of NCEP2 which was produced with support from the US National Weather Service and PCMDI (US Dept. of Energy). GPCP precipitation data was provided by the NOAA/OAR/ESRL PSD, Boulder, Colorado, USA from their website at http://www.esrl.noaa. gov/psd/. ECMWF ERA-Interim data used in this study have been obtained from the ECMWF data server.

Open Access This article is distributed under the terms of the Creative Commons Attribution 4.0 International License (http://creativecommons.org/licenses/by/4.0/), which permits unrestricted use, distribution, and reproduction in any medium, provided you give appropriate credit to the original author(s) and the source, provide a link to the Creative Commons license, and indicate if changes were made.

\section{References}

Adler RF, Huffman GJ, Chang A, Ferraro R, Xie P, Janowiak J, Rudolf B, Schneider U, Curtis S, Bolvin D, Gruber A, Susskind J, Arkin P (2003) The version 2 global precipitation climatology project (GPCP) monthly precipitation analysis (1979-Present). J Hydrometeorol 4:1147-1167

Allan R, Ansell T (2006) A new globally complete monthly historical gridded mean sea level pressure dataset (HadSLP2): 1850-2004. J Clim 19:5816-5842 
Allen RJ, Sherwood SC, Norris JR, Zender CS (2012) Recent Northern Hemisphere tropical expansion primarily driven by black carbon and tropospheric ozone. Nature 485:350-354

Anderson DLT, Gill AE (1975) Spin-up of a stratified ocean, with applications to upwelling. Deep-Sea Res 22:583-596

Balmaseda MA, Vidard A, Anderson DLT (2008) The ECMWF ocean analysis system: ORA-S3. Mon Weather Rev 136:3018-3034

Balmaseda MA, Mogensen K, Weaver A (2013) Evaluation of the ECMWF ocean reanalysis ORAS4. Q J R Meteorol Soc. doi:10.1002/qj.2063

Barreiro M, Giannini A, Chang P, Saravanan R (2004) On the role of South Atlantic atmospheric circulation in tropical Atlantic variability. Geophys Monogr Ser 147:1-16

Behringer DW, Xue Y (2004) Evaluation of the global ocean data assimilation system at NCEP: The Pacific Ocean. In: Proceedings of paper presented at the Eighth Symposium on Integrated Observing and Assimilation System for Atmosphere, Oceans, and Land Surface, American Meteorology of the Society, Seattle, Wash., 11-15 Jan

Bosilovich MG, Robertson FR, Chen J (2011) Global energy and water budgets in MERRA. J Clim 24:5721-5739

Chang P, Ji L, Li H (1997) A decadal climate variation in the tropical Atlantic Ocean from thermodynamic air-sea interactions. Nature 385:516-518

Chiang JCH, Kushnir Y, Giannini A (2002) Deconstructing Atlantic intertropical convergence zone variability: influence of the local cross-equatorial sea surface temperature gradient and remote forcing from the eastern equatorial Pacific. J Geophys Res 107:4004. doi:10.1029/2000JD000307

Choi J, Son S-W, Lu J, Min S-K (2014) Further observational evidence of Hadley cell widening in the Southern Hemisphere. Geophys Res Lett 41:2590-2597. doi:10.1002/2014GL059426

Colberg F, Reason CJC (2006) A model study of the Angola Benguela frontal zone: sensitivity to atmospheric forcing. Geophys Res Lett 33:L19608. doi:10.1029/2006GL027463

Cook KH, Vizy EK (2015) Detection and analysis of an amplified warming of the Sahara Desert. J Clim (accepted)

Cook C, Reason CJC, Hewitson B (2004) Wet and dry spells within particularly wet and dry summers in south African summer rainfall region. Clim Res 26:17-31

Dee D, Fasullo J, Shea D, Walsh J, National Center for Atmospheric Research Staff (eds). The Climate Data Guide: Atmospheric Reanalysis: Overview \& Comparison Tables. Last modified 05 Nov 2014 https://climatedataguide.ucar.edu/climate-data/ atmospheric-reanalysis-overview-comparison-tables

Dee DP, Uppla SM, Simmons AJ, Berrisford P, Poli P, Kobayashi S et al (2011) The ERA-Interim reanalysis: configuration and performance of the data assimilation system. Q J R Meteorol Soc 137:553-597. doi:10.1002/qj.828

Fauchereau N, Trzaska S, Richard Y, Roucou P, Camberlin P (2003) Sea-surface temperature co-variability in the southern Atlantic and Indian Oceans and its connections with the atmospheric circulation in the southern hemisphere. J Clim 23:663-677

Florenchie P, Lutjeharms JRE, Reason CJC, Masson S, Rouault M (2003) The source of Bengula Niños in the South Atlantic Ocean. Geophys Res Lett 30:1505. doi:10.1029/2003GL017172

Foster MJ, Heidinger A (2013) PATMOS-x: results from a diurnally corrected 30-yr satellite cloud climatology. J Clim 26:414-425

Fu R, Dickinson RE, Chen MX, Wang H (2001) How do tropical sea surface temperatures influence the seasonal distribution of precipitation in the equatorial Amazon. J Clim 14:4003-4026

Grodsky SA, Carton JA, Bingham FM (2006) Low frequency variation of sea surface salinity in the tropical Atlantic. Geophys Res Lett 33:L14604. doi:10.1029/2006GL026426

Haarsma RJ, Campos EJD, Hazeleger W, Severijns C, Piola AR, Molteni F (2005) Dominant modes of variability in the South
Atlantic: a study with a hierarchy of ocean-atmosphere models. J Clim 18:1719-1735

Hardman-Mountford NJ, Richardson AJ, Agenbag JJ, Hagen E, Nykjaer L, Shillington FA, Villacastin C (2003) Ocean climate of the South East Atlantic observed from satellite data and wind models. Prog Oceanogr 59:181-221

Harris I, Jones PD, Osborn TJ, Lister DH (2014) Updated high resolution grids of monthly climatic observations and the CRU TS3.10 dataset. Int J Climatol 34:623-642

Hastenrath S, Greischar L (1993) Circulation mechanisms related to northeast Brazil rainfall anomalies. J Geophys Res 98:5093-5102

Hastenrath S, Heller L (1977) Dynamics of climatic hazards in northeast Brazil. Q J R Meteor Soc 110:411-425

Heidinger AK, Evan AT, Foster MJ, Walther A (2012) A naïve Bayesian cloud-detection scheme derived from CALIPSO and applied within PATMOS-x. J Appl Meteorol Climatol 51:1129-1144

Höflich O (1984) Climate of the South Atlantic Ocean. In: van Loon $\mathrm{H}$ (ed) World survey of climatology, climates of the oceans, vol 15. Elsevier, Amsterdam, p 191

Hu Y, Fu Q (2007) Observed poleward expansion of the Hadley circulation since 1979. Atmos Chem Phys 7:5229-5236

Hu Y, Tao L, Liu J (2013) Poleward expansion of the Hadley circulation in CMIP5 simulations. Adv Atmos Sci 30:790-795

Hurrell JW, van Loon H (1994) A modulation of the atmospheric annual cycle in the Southern Hemisphere. Tellus 46A:325-338

Ishii M, Shouji A, Sugimoto S, Matsumoto T (2005) Objective analyses of sea-surface temperature and marine meteorological variables for the 20th century using ICOADS and the KOBE collection. Int J Climatol 25:865-879

Johanson C, Fu Q (2009) Hadley cell widening: model simulations versus observations. J Clim 22:2713-2725

Jury MR (1995) A review of research on ocean-atmosphere interactions and South African climate variability. S Afr J Sci 91:289-294

Kanamitsu M, Ebisuzaki W, Woollen J, Yang S-K, Hnilo JJ, Fiorino M, Potter GL (2002) NCEP-DOE AMIP-II reanalysis (R-2). Bull Am Meteorol Soc 83:1631-1643

Kara AB, Rochford PA, Hurlburt HE (2003) Mixed layer depth variability over the global ocean. J Geophys Res. doi:10.1029/2000JC000736

Keenlyside NS, Latif M (2007) Understanding equatorial Atlantic interannual variability. J Clim 20:131-142

Kobayashi S, Ota Y, Harada Y, Ebita A, Moriya M, Onoda H, Onogi K, Kamahori H, Kobayashi C, Endo H, Miyaoka K, Takahashi K (2015) The JRA-55 Reanalysis: general specifications and basic characteristics. J Meteorol Soc Jpn. doi:10.2151/jmsj.2015-001

Kodama YM (1992) Large-scale common features of subtropical precipitation zones (the Baiu frontal zone, the SPCZ, and the SACZ). Part I: characteristics of subtropical frontal zones. J Meteorol Soc Jpn 70:813-835

Kumar A, Zhang L, Wang W (2013) Sea surface temperature-precipitation relationship in different reanalyses. Mon Weather Rev 141:1118-1123

Lenters JD, Cook KH (1995) Simulation and diagnosis of the regional summertime precipitation climatology of South America. J Clim 8:2988-3005

Lenters JD, Cook KH (1999) Summertime precipitation variability over South America: role of the large-scale circulation. Mon Weather Rev 127:409-431

Lu J, Vecchi GA, Reichler T (2007) Expansion of the Hadley cell under global warming. Geophys Res Lett 34:L06805. doi:10.10 29/2006GL028443

Lu J, Deser C, Reichler T (2009) Cause of the widening of the tropical belt since 1958. Geophys Res Lett 36:L03803. doi:10.1029/ 2008GL036076

Manatsa D, Morioka Y, Behera SK, Yamagata T, Matarira CH (2013) Link between Antarctic ozone depletion and summer warming over southern Africa. Nat Geosci 6:934-939 
Mason SJ (1995) Sea-surface temperature-South African rainfall associations, 1910-1989. Int J Climatol 15:119-135

McLandress C, Shepherd TG, Scinocca JF, Plummer DA, Sigmond M, Jonsson AI, Reader MC (2011) Separating the dynamical effects of climate change and ozone depletion. Part II: Southern Hemisphere troposphere. J Clim 24:1850-1868

Morioka Y, Tozuka T, Yamagata T (2011) On the growth and decay of the subtropical dipole mode in the South Atlantic. J Clim 24:5538-5554

Morioka Y, Tozuka T, Masson S, Terray P, Luo JJ, Yamagata T (2012) Subtropical dipole modes simulated in a coupled general circulation model. J Clim 25:4029-4047

Nguyen H, Evans A, Lucas C, Smith I, Timbal B (2013) The Hadley circulation in reanalyses: climatology, variability, and change. J Clim 26:3357-3376

Nnamchi HC, Li J, Anyadike RNC (2011) Does a dipole mode really exist in the South Atlantic Ocean? J Geophys Res. doi:10.1029/ 2010JD015579

Nobre P, Shukla J (1996) Variations of sea surface temperature, wind stress, and rainfall over the tropical Atlantic and South America. J Clim 9:2464-2479

Novella NS, Thiaw WM (2013) African rainfall climatology version 2 for famine early warning systems. J Appl Meteorol Climatol 52:588-606

Peterson RG, Stramma L (1991) Upper-level circulation in the South Atlantic Ocean. Prog Oceanogr 26:1-73

Polo I, Rodríguez-Fonseca B, Losada T, García-Serrano J (2008) Tropical Atlantic variability modes (1979-2002). Part I: time-evolving SST modes related to West African rainfall. J Clim 21:6457-6475

Polvani LM, Kushner PJ (2002) Tropospheric response to stratospheric perturbations in a relatively simple general circulation model. Geophys Res Lett 29:1114. doi:10.1029/2001GL014284

Polvani L, Waugh D, Correa G, Son S-W (2011) Stratospheric ozone depletion: the main driver of twentieth-century atmospheric circulation changes in the Southern Hemisphere. J Clim 24:795-812

Quan X-W, Diaz HF, Hoerling MP (2004) Change of the tropical Hadley cell since 1950. In: Diaz HF, Bradley RS (eds) The hadley circulation: present, past and future. Kluwer Academic, Berlin, pp 85-120

Quan X-W, Hoerling MP, Perlwitz J, Diaz HF, Xu T (2014) How fast are the tropics expanding? J Clim 27:1999-2013

Rácz Z, Smith RK (1999) The dynamics of heat lows. Q J R Meteorol Soc 125:225-252

Randel WJ, Wu F (1999) Cooling of the Artic and Antarctic polar stratospheres due to ozone depletion. J Clim 12:1467-1479

Reason CJC, Jagadheesha D (2005) A model investigation of recent ENSO impacts over southern Africa. Meteorol Atmos Phys 89:181-205

Reason CJC, Florenchie P, Rouault M, Veitch J (2006) Influence of large scale climate modes and the Agulhas System variability on the BCLME region. In: Shannon V et al (eds) Benguela: predicting a large marine ecosystem. Elsevier, Amsterdam, pp 225-241

Reynolds RW, Rayner NA, Smith TM, Stokes DC, Wang W (2002) An improved in situ and satellite SST analysis for climate. J Clim 15:1609-1625

Reynolds RW, Smith TM, Liu C, Chelton DB, Casey KS, Schlax MG (2007) Daily high-resolution-blended analyses for sea surface temperature. J Clim 20:5473-5496

Richter I, Behera SK, Masumoto Y, Taguchi B, Komori N, Yamagata $\mathrm{T}$ (2010) On the triggering of Benguela Niños: remote equatorial versus local influences. Geophys Res Lett 37:L20604. doi:10.10 29/2010GL044461

Rienecker MM, Suarez MJ, Gelaro R, Todling R, Bacmeister J, Liu E, Bosilovich MG, Schubert SC et al (2011) MERRA: NASA's modern-era retrospective analysis for research and applications. J Clim 24:3624-3648. doi:10.1175/JCLI-D-11-00015.1
Robertson FR, Bosilovich MG, Chen J, Miller TL (2011) The effect of satellite observing system changes on MERRA water and energy fluxes. J Clim 24:5197-5217

Rodwell MJ, Hoskins BJ (2001) Subtropical anticyclones and summer monsoons. J Clim 14:3192-3211

Rossow WB, Schiffer RA (1999) Advances in understanding clouds from ISCCP. Bull Am Meteorol Soc 80:2261-2288

Rouault M, Illig S, Bartholomae C, Reason CJC, Bentamy A (2007) Propagation and origin of warm anomalies in the Angola Benguela upwelling system in 2001. J Mar Syst 68:473-488. doi:10.1016/j.jmarsys.2006.11.010

Rouault M, Servain J, Reason CJC, Bourlès B, Rouault MJ, Fauchereau N (2009) Extension of PIRATA in the tropical south-east Atlantic: an initial one-year experiment. Afr J Mar Sci 31:63-71

Ruiz-Barradas A, Carton JA, Nigam S (2000) Structure of interannual-to-decadal climate variability in the Tropical Atlantic sector. J Clim 13:3285-3297

Seidel DJ, Randel WJ (2008) Recent widening of the tropical belt: evidence from tropopause observations. J Geophys Res 112:D20113. doi:10.1029/2007JD008861

Seidel DJ, Fu Q, Randel WJ, Reichler TJ (2008) Widening of the tropical belt in a changing climate. Nat Geosci 1:21-24

Servain J (1991) Simple climatic indices for the tropical Atlantic Ocean and some applications. J Geophys Res 96:15137-15146

Servain J, Caniaux G, Kouadio YK, McPhaden MJ, Araujo M (2014) Recent climatic trends in the tropical Atlantic. Clim Dyn 43:3071-3089

Shannon LV, Boyd AJ, Bundrit GB, Taunton-Clark J (1986) On the existence of an El Niño-type phenomenon in the Benguela system. J Mar Sci 44:495-520

Staten P, Rutz J, Reichler T, Lu J (2011) Breaking down the tropospheric circulation response by forcing. Clim Dyn 39:23612375. doi:10.1007/s00382-011-1267-y

Sterl A, Hazeleger W (2003) Coupled variability and air-sea interaction in the South Atlantic Ocean. Clim Dyn 21:559-571

Stramma L, England M (1999) On the water masses and mean circulation of the South Atlantic Ocean. J Geophys Res 14:20863-20883

Sutton RT, Jewson SP, Rowell DP (2000) The elements of climate variability in the tropical Atlantic region. J Clim 13:3261-3284

Thompson DW, Solomon S (2002) Interpretation of recent Southern Hemisphere climate change. Science 296:895-899

Thompson DW, Wallace JM (2000) Annular modes in the extratropical circulation. Part I: month-to-month variability. J Clim 13:1000-1016

Thompson DW, Wallace JM, Hegerl GC (2000) Annular modes in the extratropical circulation. Part II: trends. J Clim 13:1018-1036

Trenberth KE, Olson JG (1989) Temperature trends at the South Pole and McMurdo Sound. J Clim 2:1196-1206

Venegas SA, Mysak LA, Straub DN (1997) Atmosphere-ocean coupled variability in the South Atlantic. J Clim 10:2904-2920

Vigaud N, Richard Y, Rouault M, Fauchereau N (2009) Moisture transport between the South Atlantic Ocean and southern Africa: relationships with summer rainfall and associated dynamics. Clim Dyn 32:113-123

Walker ND (1990) Links between South African summer rainfall and temperature variability of the Agulhas and Benguela Current Systems. J Geophys Res 95:3297-3319

Xie S, Carton J (2004) Tropical Atlantic variability: Patterns, mechanisms, and impacts. In: Wang C, Xie S-P, Carton JA (eds) Earth's climate: the Ocean-Atmosphere Interaction, Geophysical Monograph Series, vol. 147. AGU, Washington, DC, pp 121-142

Yuan C, Tozuka T, LuoJ-J Yamagata T (2014) Predictability of the subtropical dipole modes in a coupled ocean-atmosphere model. Clim Dyn 42:1291-1308

Zebiak S (1993) Air-sea interaction in the equatorial Atlantic region. J Clim 6:1567-1586

Zwiers FW, von Storch H (1995) Taking serial correlation into account in tests of the mean. J Clim 8:336-351 